\title{
Forum
}

As a regular feature of Religion and American Culture, the editors invite scholars to comment from different perspectives upon an issue or a problem central to the study of religion in its American context. The FORUM format is designed to foster the crossdisciplinary study of religion and American culture and to bring to the readers of the journal the latest thoughts of scholars on timely, substantial topics. Contributors to the FORUM are asked to present brief essays or "thought pieces" instead of carefully documented articles.

\section{Studying Religion in the Age of Trump}

There are many ways to interpret the election of 2016. From appeals to anti-immigrant and anti-Muslim sentiments to attacks on the establishment and political correctness, alongside more traditional topics like abortion, religious freedom, and ethics, enough subterranean shifts occurred to flip some states red and elect a populist president.

What role did religion in play in these events? How might this election cause us to rethink some seemingly settled conclusions about religion and politics, religion and race, and religion and gender, among other topics? Finally, what might we learn from the election of 2016 that will alter our questions and further our work over the next several years?

In this special FORUM issue, we have asked prominent scholars representing multiple disciplines to consider where we might turn our attention. All of them have published on subjects that have helped us understand different aspects of religion and American culture in ways that shed light on the nature of religion in politics and public life. It is an appropriate moment for us all to look back at how we arrived at previous conclusions, question which interpretations might suitably be shaken up, and consider where our fields might fruitfully go in the coming years.

Religion and American Culture: A Journal of Interpretation, Vol. 27, Issue 1, pp. 2-56, ISSN: 1052-1151, electronic ISSN: 1533-8568. @ 2017 by The Center for the Study of Religion and American Culture. All rights reserved. Please direct all requests for permission to photocopy or reproduce article content through the University of California Press's Reprints and Permissions web page, http://www.ucpress.edu/journals.php?p=reprints. DOI: https://doi.org/10.1525/rac.2017.27.1.2. 


\section{Randall Balmer}

Exit polls from the election just past suggest that as many as 81 percent of voters who identify as evangelicals in the United States cast their ballots for the Republican nominee, Donald J. Trump. Beginning in the late 1970s, this constituency of politically conservative evangelicals, known collectively as the Religious Right, has contributed mightily to the transformation of the American political landscape by providing the Republican party with its most reliable constituency, much the way that labor unions once served as the backbone of the Democratic party. For much of the past three decades, until the 2016 election, leaders of the Religious Right emphasized the importance of "family values," which entailed opposition to divorce, equal rights for women, homosexuality, same-sex marriage, sex trafficking, and abortion.

The embrace of Trump, therefore, seems anomalous. Twice divorced and thrice married (as were two of his principal surrogates during the campaign, Rudy Guiliani and Newt Gingrich), Trump would seem an unlikely oracle for family values. Add to that, his opposition to abortion, which the Religious Right claims as its signature issue, was inconsistent at best.

Why, then, would evangelicals flock to Trump in the 2016 presidential election? Surely the longstanding animus toward the Democratic nominee, Hillary Rodham Clinton, stoked relentlessly over the decades by leaders of the Religious Right, played a role, but that explanation is inadequate. If leaders of the Religious Right were truly serious about promoting family values, they could never in good conscience support a vulgar candidate with little evident piety, a welldocumented history of disparaging comments and predatory behavior toward women, and a checkered marital past, which included boasting about his infidelities.

On the face of it, therefore, the evangelical embrace of Trump utterly defies reason. To justify their support for such a manifestly flawed candidate, evangelicals would need to set aside everything they have affirmed for the last three-plus decades. But the defect in this line of interpretation lies in viewing evangelical political activism since the late 1970s as principled engagement rather than what it was: naked partisan loyalty with roots in racism.

\section{The Abortion Myth}

When writing his autobiography, Jerry Falwell, pastor of Thomas Road Baptist Church in Lynchburg, Virginia, and one of the founders of the Religious Right, recalled his consternation at reading 
about the Supreme Court's Roe v. Wade decision of 1973. In Falwell's telling (admittedly fourteen years later), his immediate reaction was concern for all of the innocent lives that would be lost because of the Court's misguided ruling. His second response was rage and the determination to mobilize politically in order to reverse that decision-even though, by his own admission, Falwell did not preach an antiabortion sermon for another five years.

Similar accounts from other leaders of the Religious Rightincluding Pat Robertson, James Dobson, and others-have burnished this narrative. Some evangelical leaders even claimed the moniker new abolitionist in order to align themselves with their evangelical forbears and their fight against the scourge of slavery.

The rhetoric about abortion being the catalyst for the rise of the Religious Right, however, collapses under scrutiny. Evangelicals considered abortion a "Catholic issue" for most of the 1970s. In 1968, the flagship evangelical magazine Christianity Today convened a conference with another evangelical organization, the Christian Medical Society, to discuss the ethics of abortion. After several days of deliberations, the participants issued a statement acknowledging that they could not agree on any one position, that the ambiguities of the issue allowed for many different approaches. "Whether the performance of an induced abortion is sinful we are not agreed," the statement read, "but about the necessity of it and permissibility for it under certain circumstances we are in accord." Meeting in St. Louis in 1971, the messengers (delegates) of the Southern Baptist Convention passed a resolution calling for the legalization of abortion. The Convention, hardly a bastion of liberalism, reaffirmed that position in 1974 (the year after Roe $v$. Wade) and again in 1976.

When the Roe decision was handed down, several prominent evangelicals, including the redoubtable W. A. Criswell, pastor of First Baptist Church in Dallas, hailed the ruling. W. Barry Garrett of Baptist Press wrote that "religious liberty, human equality and justice are advanced by the Supreme Court abortion decision."

\section{What Really Happened}

In November 1990, I was invited to a closed-door conference in Washington, D.C., celebrating the ten-year anniversary of Ronald Reagan's election to the presidency. In addition to fellow historians George Marsden and Grant Wacker, I found myself in a room with such luminaries of the Religious Right as Donald Wildmon, Ralph Reed, Richard Land, Carl F. H. Henry, and Ed Dobson, one of Falwell's acolytes in the Moral Majority. The apparent purpose of the conference 
was a ten-year retrospective on Reagan's election and presidency, and in the course of the first session, Paul Weyrich, arguably the principal architect of the Religious Right, embarked on an impassioned soliloquy in which he declared that abortion had nothing whatsoever to do with the rise of the Religious Right. Dobson agreed, and in the break immediately following the session, I sought out Weyrich to ensure that I had understood him correctly. He was emphatic. He had been trying since the Goldwater campaign in 1964 to mobilize evangelical voters, he said, by raising such issues as school prayer, pornography, the proposed Equal Rights Amendment, and abortion, but nothing galvanized evangelical leaders to action until the Internal Revenue Service began to challenge the tax-exempt status of racially segregated schools.

Indeed, the real catalyst for the Religious Right was a court decision, but it was not Roe v. Wade. It was a lower court ruling in the District Court for the District of Columbia in a case called Green $v$. Connally. On June 30, 1971, the court ruled that any organization that engaged in racial segregation or racial discrimination was not by definition a charitable institution, and therefore it had no claims on taxexempt status. The Supreme Court's Coit v. Green decision upheld the District Court, and the IRS then began making inquiries about the racial policies of so-called segregation academies as well as the fundamentalist school Bob Jones University, in Greenville, South Carolina, which boasted a long tradition of racial exclusion.

That is what caught the attention of evangelical leaders in the 1970s, including Falwell, who had opened his own segregation academy in 1967 to allow whites in the Lynchburg area to evade desegregation in the public schools. According to Weyrich-and corroborated by Ed Dobson, Richard Viguerie, Grover Nyquist, and my own research - the defense of tax exemption at Bob Jones University and at segregation academies is what persuaded evangelical leaders to become politically active in the 1970s. These institutions, moreover, had long argued that because they accepted no federal funds, they were immune to government strictures; the federal government could not tell them how to run their institutions-who to admit or not to admit, who to hire or fire.

Such casuistry, however, ignored a crucial fact: tax exemption is a form of public subsidy. The Supreme Court upheld the IRS and its denial of tax exemption in the Court's decision in the Bob Jones case in May 1983. (The sole dissenter in that ruling was William Rehnquist, whom Reagan later elevated to chief justice.)

How did abortion become part of the Religious Right's agenda? After mobilizing in opposition to the IRS, Weyrich and leaders of 
the nascent Religious Right were savvy enough to recognize that they needed another issue to rally rank-and-file evangelicals to the voting booth. The mid-term elections in 1978, when pro-life Republicans defeated favored Democratic candidates in New Hampshire, Iowa, and Minnesota, persuaded Weyrich that opposition to abortion could work as a populist issue. In both Iowa and Minnesota, pro-life activists (principally Roman Catholics) leafleted church parking lots on the final weekend of the campaign; two days later, in a plebiscite with a very low turnout, the Democratic candidates lost. Two months later, Francis A. Schaeffer, considered by many the intellectual godfather of the Religious Right, and C. Everett Koop, a pediatric surgeon, began touring the country with an antiabortion film series, Whatever Happened to the Human Race? Many evangelicals became attuned to the issue. Even so, the Reagan-Bush campaign was still uncertain about whether or not abortion would work for them politically during the 1980 presidential campaign. As late as August 1980, when Reagan addressed more than ten thousand evangelicals at a rally in Dallas, his stem-winding speech railed against evolution and the IRS, but the Republican nominee did not mention abortion.

\section{Why It Matters}

A consideration of the history of the Religious Right makes it easier to understand why evangelicals voted so overwhelmingly for Donald Trump in 2016. Evangelical political activism in the late 1970s was never about the defense of biblical or family values. Instead, the Religious Right is rooted in the defense of racial segregation, and no amount of bluster or historical revisionism can alter that fact. In casting their lot with Weyrich and the far-right fringes of the Republican party, evangelicals not only defeated one of their own, Jimmy Carter, in the 1980 election, they also forfeited the prophetic voice that had been characteristic of evangelical political activism dating back to the nineteenth century, an activism that advocated for peace, adopted a critical posture toward unbridled capitalism, and more often than not took the part of those on the margins of society, especially women and people of color.

The Faustian bargain that Falwell and others struck with the Republican party gave them access to power in the 1980s and beyond - or at least the illusion of access. In exchange, however, the prophetic voice of evangelicalism was struck dumb. Leaders of the Religious Right offered nary a whimper of protest when the Reagan administration enacted tax cuts that overwhelmingly favored the affluent at the expense of those less prosperous. They stood by in 
silence when the Reagan administration flouted environmental protections and exploited natural resources. Similarly, they offered no protest when George W. Bush initiated military engagements that would not meet even the barest criteria for a just war. Time and again, the loyalties of the Religious Right have centered on the Republican party and Republican politicians rather than the New Testament or the noble traditions of evangelical social activism in the nineteenth and early twentieth centuries. Opposition to abortion and support for "family values," at least in the hands of cynical evangelical leaders, became effective, albeit transitory, bludgeons against anyone they regarded as a political adversary.

Then in 2016, when their preferred party nominated someone with a history of shifting positions on their supposed signature issue, someone with a patchy marital past, leaders of the Religious Right simply dropped the rhetoric of family values and retreated to the redoubt of racism that undergirded the formation of their political movement. Trump's race-baiting and his excoriation of immigrants, together with his party brand, were sufficient to retain the loyalty of Religious Right leaders; 81 percent of evangelical voters followed their lead.

\section{Kate Bowler}

When I first wrote Blessed: A History of the American Prosperity Gospel, I thought that one of the most important tasks would be to explain why one of the most derided Christian movements in American history was not just a punchline but a full-orbed worldview. I wanted it to be "taken seriously," as we like to say, despite its reputation for being maudlin and smarmy. To be sure, I understood people's deep antipathy toward its preachers and its theology. I once saw a prosperity preacher transform a lovely little Christian theme park into her own image by bedazzling it with a fleet of golden lion statues and cardboard cutouts of her face. Nonetheless, I was deeply sympathetic-if almost defensive - of the movement and its ability to keep its finger on the pulse of people's deepest desires. The movement seemed to understand something profound about the American religious imagination that the wider culture was too quick to dismiss.

For all the riches gained from their bestsellers, twenty-four hour Christian programming, and packed megachurches, members of the prosperity movement coveted what they did not have. Politicians might court their churches, but not publicize their preachers' endorsements. City leaders wanted their cooperation, but not always their place on boards and councils. Universities did not clamor to give their preachers 
an honorary Ph.D., or name a concert hall after them. If a stately figure died, no one wanted to host a somber memorial service in their halls. At best, prosperity preachers smelled like new money, but there was nothing terribly respectable about the movement's public image. No one championed their causes in the halls of power. Until now.

Donald Trump is the first American president whose only religious impulses arise from the American prosperity gospel. It is well known that the Trump family attended Marble Collegiate Church in New York City, a venerable Reformed Church in America pulpit whose entrepreneurial pastor, Norman Vincent Peale, preached a theology which also became his personal brand. Peale's runaway bestseller, The Power of Positive Thinking (1952), was a sunny mix of New Thought mind-power combined with the high anthropology of mainline Protestantism. The result was a simple recipe for successful living: "as you think, so shall you be." Or, in other words, "think positively ... and you set in motion positive forces which bring positive results to pass." The mind was a spiritual powerhouse that could achieve health, wealth, and all-around happiness, a high-flying optimism that seems to have shaped Trump's youthful outlook. When he was married the first time, it was the Reverend Norman Peale who performed the wedding ceremony in the hallowed birthplace of positive thinking.

Two other strands of the prosperity gospel are woven into Trump's sparse religious biography. The businessman who relentlessly promoted himself as a self-made man found spiritual solace in a young televangelist from Florida named Paula White, whose perky twist on the Pentecostal prosperity gospel had led to books with titles like Deal with It! and her own workout videos. She was the sexy embodiment of the supernatural bootstrapping of prosperity theology, a self-proclaimed "messed-up Mississippi girl" whose life, once marred with abuse and neglect, was reborn to success by living according to the divine laws of faith. Of the scores of prosperity preachers in the public eye, White was famous for being the queen of second chances, as she has remade her own ministry several times after living many lives as the former protégé of African American superstar T. D. Jakes, one-time televangelist (now online personality) and senior pastor of a megachurch whose fortunes rose and fell with hers. Along with the virtually unknown prosperity pastor Mark Burns, White became a cheerful stumper for Trump on the campaign trial and joined Texas televangelists Gloria and Kenneth Copeland on his religious board of advisors.

For the first time in American history, a president-elect instinctively turned first to prosperity thinkers to shape his religious thinking about what might "Make America Great Again." As Trump's connections to positive thinking and Pentecostal prosperity preaching are 
combined with his blatant American exceptionalism, we can see that the three strands of what historically constitutes the prosperity gospel have been woven together. Trump is, in short, the prosperity gospel's religious trifecta.

Until this election season, it seemed entirely plausible that the arc of the American prosperity gospel would bend away from the political and toward the therapeutic. After all, the two most-watched Christian televangelists in the world are Joel Osteen and Joyce Meyer, prosperity preachers who built their ministerial empires on apolitical topics such as self-esteem and emotional management. In fact, it was this turn toward therapeutic paradigms that saved the prosperity gospel from disgrace when, in the late 1980s and early 1990s, hard-sell prosperity preachers like Jim Bakker made the movement a laughingstock. Bakker's much-publicized sexual and financial misdeeds seemed synonymous with the image of the slick televangelist weeping and begging crowds for cold cash, and so the televangelists that took his place adopted a gentler approach. In keeping with the darker, postmodern mood of the mid-1990s, they took up issues of psychological transformation, promising to sell audiences "tools" to improve their self-esteem rather than simply asking for donations. While Jim Bakker had once hosted flag-waving television specials and Tammy Faye crooned "America the Beautiful," giants of the 1990s like T. D. Jakes galvanized audiences with frank talk about sexual abuse with his Woman Thou Art Loosed! franchise. The message of divine health and wealth was still clear, but the therapeutic ministrations of what I call "soft prosperity" emphasized the spiritual and material benefits of a "renewed mind." The battle was interior, not exterior, to the self.

In the United States, the prosperity gospel's promise that rightthinking and right-speaking Christians triumphed over any obstacle has always made the role of politics rather ambivalent. Its heavily individualistic nature leans away from structural indictments or solutions, for the answer always lies within. As such, the prosperity gospel's end run around systems of oppression-whether those systems be failing markets or failing governments-dulls its political edge. When I tracked the Twitter responses of the nation's leading prosperity preachers to the Great Recession and the government shutdown, for instance, responses were characteristically optimistic and bland, urging people to turn to God, not Washington, for results. At times, apocalyptically minded prosperity preachers posited that there might be an "End Times Wealth Transfer" which would right the wrongs of Wall Street, but, even then, God would bulldoze a divine path.

There were, of course, exceptions to this paradigm. Depending on the racial and regional demographics, lesser-known megachurch 
pastors might take a side. African American prosperity preachers, if they had historic denominational ties, usually supported presidential candidates (sometimes Democratic, sometimes Republican) and maintained a presence in city politics. Latino prosperity preachers, particularly in Florida, were stalwart Republicans with favorite political candidates who might visit their megachurches now and again. And then, of course, there were holdouts from the 1980s heyday of the Religious Right. Pastors John Hagee, Rod Parsley, Kenneth and Gloria Copeland, and others, remained the bullhorns of "family values" espoused by political darlings who came and went. But most national figures in the prosperity movement were not seen as those with an axe to grind. Their wide appeal was owing, in part, to their deliberate silence come election season.

Are we seeing the evolution of the prosperity gospel in the era of Trump? Has the prosperity gospel now gained new political traction? Yes and no. Certainly, Donald Trump is a deeply ambivalent hero for any religious movement, since his only explicit religious beliefs seem to be impulses rather than a deeply held worldview and his spiritual loyalties seem malleable. Trump's rise likely says more about evangelical political sway and the persistence of the Religious Right's powerbrokers than it does about the prosperity movement as a whole. In the course of the campaign, Trump became the unlikely advocate for hot-button evangelical issues - a three-time married man fighting for "traditional families," a sexual braggart at the helm of a purityobsessed culture. But, in other ways, his individualistic vision of selfmade men, saddled with righteous causes, a smaller government, and a vision of Christian America, galvanized voters and offered Trump Washington allies forged in the fires of past evangelical culture wars.

In other respects, however, Trump is perhaps the most stunning example of the success of the prosperity gospel in casting a vision of the self-made American. The prosperity gospel is fundamentally a theology that explains away luck. It is a pragmatic, resultsbased, and therapeutic set of beliefs and practices that explain to believers why some people rise to the top and others plummet to the very bottom. But it is not simply a theodicy. These new religious conceptions of the self-constituting individual sprang up, in part, in response to late capitalism as a strategy for managing a new set of economic conditions. As countless histories of neoliberalism have documented, the privatization and reduction of social services characteristic of this age have forced people to turn toward the market as a source of choice and solution-oriented thinking. But its freedoms are also its burdens. A workforce promised flexibility is likely given fewer employee benefits and stable hours; risk and instability are 
woven into the fabric of the modern workplace. Prosperity believers know that the market is a fickle God, but they share its vision of the resourceful person who can persevere.

The prosperity gospel, in explaining how to succeed, is very deliberate in showing believers how to account for their faith, how to tabulate their efforts and count change in their lives. On the whole, believers do not typically experience the prosperity gospel as a random occurrence, like an unexpected miraculous healing or a mysterious envelope of cash found in a mailbox; rather, they learn a spiritual calculus that they use to weigh all actions as religious labor, from singing in church to smiling at work. I would argue that much of the theological effort of prosperity churches is directed toward cultivating an alternative imagination, teaching believers how to recast their spiritual lives as labor measurable in divine currency and redeemable for earthly rewards. This is the how of the prosperity gospel, the patterns and tools and imagination that believers acquire to set the prosperity gospel in motion. The prosperity gospel has popularized instruments by which to count change in an era of tremendous ambiguity around what constitutes paid work, and it has successfully promoted a vision of the Christian life lived inside overlapping cosmic and American economies.

Like Donald Trump's Think Big and Think Like a Champion, the economy of the American prosperity gospel was fueled by positivity, ambition, and steely resolve to stand alone if need be. It effectively explained away the role of chance, systemic obstacles, education, advantage, race, age, gender, generational wealth, and even skill in explaining why one worker thrived and another floundered. Believers imagined their workplace was governed by spiritual lessons and divine rewards. Instead of a faceless system, believers saw the invisible working of a God who never saw his children as just another cog in the machine.

In the past, when asked about the political future of the prosperity gospel, I have always said that the American prosperity gospel did not need politics. Unlike Brazil, Nigeria, or Guatemala, where iterations of the prosperity gospel have evolved into hungry political parties, the American prosperity gospel did not seem to require a collective partisan platform, well-suited as it was to a nation where people still believed that, with a little divine boost, they could make it on their own. But it appears that we are at the dawn of a new era of political respectability of the prosperity gospel, a time when a prophet of divine wealth might speak at the National Prayer Breakfast or eat a leisurely dinner at the White House. Just as Nigeria's broad 1980s Pentecostalism gave way to a 1990s prosperity gospel in the wake of major 
privatization, perhaps the United States is simply adjusting its theological sails to the new economic winds. Though the prosperity gospel has never been directly tied to the markets in a simplistic way-faring as well in the economic boom years of the 1920s as it did during the lean 1930s - it has always been yoked to the American conception of the self.

The prosperity movement may not need a formal political party, but it has made a theological champion out of a New York businessman who has seemed impervious to risk and even failure itself. Every time Trump has fallen, he has gotten back up, somehow able to win in an unsteady world that wants to believe, with him, that there is no such thing as luck.

\section{Anthea Butler}

I have been teaching a class on the Religious Right since 2005, and, for the most part, I always have a lively class with engaged students. They are there hoping to figure out a conservative relative, their religious upbringing, or why politicians in America are so God obsessed. In the course of the semester, I take them from Billy Graham's relationship to presidents since Eisenhower, Roe v. Wade, the Moral Majority and Ronald Reagan, all the way up to George W. Bush's compassionate conservatism, and the election of Barack Obama. To put a finer point on it, I teach the class from a predominately (but not entirely) white evangelical perspective, engaging why and how evangelicals hope to influence and engage American politics, and how effective that has or has not been religiously and politically. So much for that. The 2016 election cycle has shredded my previous methodology for the course. If I am completely honest, though, I have not taught the course exactly that way since 2008. Let me explain.

The election of Donald Trump to the presidency has destroyed my thinking about evangelicals and political action and has given credence to what I knew in my gut: that our definition of "evangelical" whether based in beliefs, politics, or behavior was wrong. The people who have elected Trump are not just evangelicals, but they are a variety of religious groups that we do not normally think of as evangelical: Pentecostals, third wave, prosperity gospel, and dominionists. These are the people who surrounded Donald Trump from the very beginning and who were instrumental in supporting him online, in print, and from their pulpits, and then evangelicals decided to vote for Trump, despite their qualms about his morality. In order to understand how that happened, we will need basically to scrap what we 
think we know about the "culture wars" and deal with another trajectory altogether, one that takes seriously that the term "Religious Right" not only includes white evangelicals, but whites who come out of these other iterations of Pentecostal-like movements, including prosperity gospel. We will have to take seriously the issue of race and racism at the core of how evangelicalism is constructed, especially in twentieth-century America, and we have to deal with how capitalism fuels evangelicalism. In short, we have to start all over again. The fact that 3 percent more evangelicals voted for Trump in the 2016 election than voted for Mitt Romney in 2012 tells us all we need to know: it was not about the Bible and morality, after all.

Trump is not an aberration, but the eventual end of all evangelical political action: electing a white male candidate who reinforces biblical sexual and gender norms, is suspicious about immigrants and Islam, and, most importantly, believes in white America. Trump's "Make America Great Again" slogan appeals to what Robert Jones, the author of The End of White Christian America states: "Values Voters became Nostalgia Voters." Evangelicals especially want to bring back the good old days, but they also have changed demographically and in what is important to them. Losing same-sex marriage, Antonin Scalia, and the rise of religious freedom arguments with regard to the Affordable Care Act have all taken their toll.

In order to understand what happened this election cycle and why many people missed how Trump was able to triumph (at least in the electoral vote), I believe that many factors helped him, but one stands out: mainstream evangelicals left Ted Cruz and Marco Rubio for Trump not because he was the best candidate, but because they had been primed to leave them by events during the 2008 election cycle. Many evangelicals saw the McCain-Palin ticket as the antidote to Barack Obama and his charismatic campaign. That was a bit of revisionist history on the part of evangelicals because, of all the 2008 candidates, John McCain had an uphill battle with conservative Christian leaders. McCain, a United Methodist, had never worn his faith on his sleeve. He also did not suffer fools easily, especially religious ones. Back in 2001, McCain had called Jerry Falwell and Pat Robertson "agents of intolerance" for their proclamations after the 9/11 attack. McCain later retracted his statement against Falwell on Meet the Press in 2006 and, soon after, gave the commencement address at Liberty University.

In the 2008 election cycle, McCain's initial reticence to talk about culture war issues hurt him with evangelicals on the campaign trail. A major evangelical power broker, Dr. James Dobson, then head of Focus on the Family, stated bluntly that he would not vote for John 
McCain "under any circumstances" and would not vote in the 2008 presidential race. McCain's campaign strategists, meanwhile, realized they needed evangelical voters, but with Dobson's endorsement of Mike Huckabee and the lukewarm reception of other evangelical leaders, the campaign decided to try another route. Unlike other major Republican candidates, McCain's campaign focused on megachurch leaders who were affiliated with Pentecostalism, even if their churches were branded as "nondenominational." The distinction was, though the churches and leadership had no official denominational affiliation, they were Pentecostal in their beliefs and practices. Their statements and public presentation resembled other nondenominational evangelical churches. By courting Pentecostals, McCain could connect to a different circle of religious leaders who were as powerful as Dobson, especially in swing states like Ohio. The campaign then tapped into two powerhouses, John Hagee and Rod Parsley, in the hopes of bridging their evangelical gap. Both Hagee in Texas and Parsley in Ohio were strategic voting picks. However, they also came with baggage that McCain did not understand. Hagee and Parsley were both nondenominational Christians who believed in gifts of the spirit, demons, and dominionist theology, which each preached about regularly in sermons. McCain eventually repudiated both men because of sermons and beliefs they had promulgated.

In August 2008, John McCain settled on Sarah Palin, governor of Alaska, as his vice presidential running mate. At the time, the media called her an "evangelical." In fact, Palin was not an evangelical but was raised in an Assemblies of God church in Wasilla, Alaska, until she moved her membership to a nondenominational church right before becoming governor. Soon after the vice president announcement, Palin was shown in a video from a few years back having hands laid on her by Bishop Muthee, who was part of C. Peter Wagner's New Apostolic Reformation group. Evangelicals embraced her anyway, while pundits used her lack of knowledge about world affairs and made her a laughing stock among politicos. These events endeared Palin to the disgruntled masses.

At the same time, Palin had something those pundits did not understand-a way to articulate white identity politics under the guise of God, country, and guns. Palin, a white woman who could shoot, pray, and have babies into her forties, represented what she constantly talked about during and after the 2008 campaign was over: American exceptionalism. Many thought Palin's talk of American exceptionalism was generic, but it was not. It was really white identity politics cloaked in evangelicalism, capitalism, and an American flag. By othering Obama both before and after the 2008 
election, Palin was able to capture the disgruntled white masses under the guise of God and country. She was also able to hone the racial animus that had been growing against Barack Obama. Additionally, by alluding that Obama was "palling around with terrorists" she successfully merged terrorism, Islam, and race together to fuel hate.

Palin was shrewder than many believed. Her language and actions paved the way for Donald Trump's MAGA-Make America Great Again-campaign in 2016. Palin was not an aberration in the 2008 election cycle; rather, she was the eventual end result for John McCain. The mistake that many made back in 2008 was lumping Palin in with regular evangelicals when it was clear that her associations were a combination of Pentecostals, dominionists, and evangelicalswho all had aspirations for her to be in public office.

Since 2008, Palin has given voice to grievances about the government through the Tea Party movement and to how President Obama was changing the country with screeds like "death panels," "crony capitalism," and the like. While the mainstream media discounted her statements, right wing outlets, many of which conservative Christians listened to, promoted her statements alongside other conspiracy media outlets like Glenn Beck and Alex Jones. Palin channeled white working-class identity politics long before what is now referred to as the "Alt-Right." By coding her language with common sense conservatism-real, "small town Americans"- - her language hearkened back to a simpler time when America was seen as predominantly white Anglo Saxon Protestant, with other ethnic groups aspiring to be WASPs or, as coded, Americans. By othering the first black president with a Muslim sounding name, Palin and the McCain campaign set a firm foundation for Trump to stand on in the 2016 election cycle.

The 2008 election inflected Trump's run in 2016 in various ways. First, it relied on support not from mainstream evangelical leaders, but from prosperity gospel leadership like Paula White and other D-list luminaries such as Mark Burns and Darren Scott. The emphasis on God's blessing through prosperity enabled Trump to reach a demographic not often thought of as evangelical. Prosperity gospel adherents believe much of what mainline evangelicals do with regards to abortion and same-sex marriage, yet they also embrace capitalism and wealth as signs of God's blessing. Trump, with his own brand of promoting prosperity, was an ideal candidate for attracting these voters. Evangelical voters went along for the ride because Trump pandered to their concerns on abortion and the very coveted Supreme Court nomination. 
Second, the politics of grievance and white identity, coupled with patriotism and American exceptionalism, became the core of Donald Trump's message. While Palin had energized parts of the populace with a similar yet scattered message, Trump's clear message to "Make America Great Again" plus a willingness to go beyond a dog whistle to a full on bullhorn, while crass in many ways, resonated with many evangelicals. To describe these evangelicals who had pinned their hopes on Sarah Palin back in 2008, David Brody coined the term, "Teavangelicals" - evangelicals who wanted limited government, limited spending, and better jobs, while desiring mainstream evangelical concerns to be addressed like abortion and same-sex marriage.

Finally, Trump's combination of reality show/televangelist persona made for a potent mix of camera-ready and media-savvy promotion. Evangelicals may have balked for a second at three wives, numerous crass statements, and gold-plated Trump properties, but, in the end, the combination of whiteness, prosperity gospel, televangelist fervor, and promises to "Make America Great Again" overshadowed any moral qualms. Besides, evangelicals know that God can use anyone-even Balaam's ass, right? - to proclaim the truth of God. In this case, however, the fallout may come back to bite them, even though Trump is appointing many people who are sympathetic to evangelical beliefs and causes.

In order to understand what happened with Trump, we will have to take a hard look at the historical narratives we have taught and written about regarding the rise of the Religious Right in America. As scholars, we took seriously what conservatives told us they believed about morality, abortion, homosexuality, and the like. With the election of Donald Trump and the myriad excuses evangelicals proffered about why they voted for him, it is time we take seriously their voting patterns, and not just their words. It is also up to scholars of American religion and politics to reassess our assumptions about who evangelicals actually are, including their political action beginnings, and look for a new narrative. Maybe the gap between Reagan and Trump is not so large after all.

\section{Maura Jane Farrelly}

During a recent conversation with a devoutly Catholic, Trump-supporting acquaintance, the name Jeremiah Wright came up. The person I was speaking with was critical of the people who protested Donald Trump's victory in the weeks that followed his election. "They stuck with Obama even though he attended the church of that 
racist, Jeremiah Wright," the acquaintance said to me, explaining his vote. "Trump's not perfect. He's said some bad things. But those losers should stop whining and accept the election results."

I asked this man if he'd attended mass even at the height of the clerical sex abuse crisis here in Boston. He told me that he had. "That must have been because you subscribed to the same principle that Barack Obama did," I remarked. "Remember how he explained to us that for him, the church isn't any one minister or priest? For him, the church is the people of God."

I then suggested to my conversation partner that this idea might be useful to him, if he wanted to try to understand what the protesters were actually resisting. Certainly they were upset that their candidate had lost, but any liberal over the age of twenty-nine already knows what losing a presidential election feels like. It wasn't the reality that they'd "lost" that the protesters were resisting, and contrary to the narrative taking root on the Trump side, their demonstrations were not the unsophisticated cries of a "trophy generation" that had never been allowed to keep score in a soccer game. The protesters also weren't resisting the reality that Donald Trump will soon be their president (although I know that many of their slogans and hashtags did suggest otherwise). Without a doubt, the people who poured into the streets after the election found the prospect of a Trump presidency to be distasteful, and they were there because they were alarmed by the few policy initiatives that Trump actually bothered to speak about during his campaign. It's undeniable that on some level the demonstrations were meant to be a warning to the president-elect: "Don't do what you said you were going to do, or else you will have to deal with us."

Sending a warning, however, isn't the same thing as resisting a change, and I do think the protesters were resisting a change in America when they took to the streets. I just don't think the change they were resisting was the one that's going to happen under Trump. In the clear light of day, I suspect many of the people who demonstrated-if they have any understanding at all of how government actually works - realize that Trump is going to have a hard time building a wall along the Mexican border or deporting millions of immigrants (who are, not incidentally, responsible for harvesting the bulk of our nation's food supply). Trump's campaign promises were abhorrent, but I don't think those promises, which have yet to be fulfilled, were what the protesters were actually resisting when they blocked traffic on Chicago's Lake Shore Drive and hung effigies in Los Angeles' MacArthur Park. The promises were not responsible for the real sense of dread and even heartbreak that animated the demonstrations in the days after November 8, 2016. The president, after all-much like 
Jeremiah Wright-is just one leader. The church isn't one minister, and "America" isn't one president. America is and always has always been the people of the United States.

That, then, is the reason so many people took to the streets in the days after the election, marching through cities like San Francisco, Boston, and Denver and condemning Donald Trump's democratic victory before the billionaire real estate developer had even had a chance to open the doors of the White House to the specter of white nationalism. The protesters were heartbroken by Trump's victory because it was democratic. The demonstrations were a collective act of resistance against what the people of the United States-that is to say, our "church"-may have become on November 8 .

Even though Hillary Clinton won the popular vote, the fact remains that, in this year's election, a critical mass of people in the United States chose to reward a man who released a dehumanizing spirit onto our land. These voters believed they were rejecting the status quo, and their votes were as much about the real pains of globalization as they were about the belief that Hillary Clinton is crooked to the core. Yet they also knowingly and willingly accepted Donald Trump's destruction of our political discourse when they went to the polls, and they committed our church to a very different premise from the one it was founded upon. This changed premise, I believe, is what the protesters were resisting (though I am not sure all of them were equipped to articulate their resistance in this way-and if I'm right about that, then we, their teachers, bear some responsibility for their failure to understand the very forces that were motivating them).

Just like the Catholic church, the United States was founded upon a principle-a "theology," if you will. That principle was the extraordinary and unprecedented idea that rights are something inherent in each individual by virtue of his or her humanity. Not even the rights-oriented political culture of England made such an audacious claim at the time, as rights in that culture were tied inextricably to English identity and to the country's status as a Protestant nation.

In the United States, however, rights were said to be an "unalienable" attribute of "all men." Certainly that principle was violated by the very people who composed the first verses of America's sacred writ-and scholars have done some great work over the course of the last forty years or so in constructing a historical narrative that obliges Americans to confront that truth about their church's founding. But the whole of this country's imperfect and stained history up until this point has been about the excruciatingly difficult challenge of making America's founding principle a reality. And on November 8, the people of the United States voted to place our church on a different foundation. 
Donald Trump's victory signals that rights may no longer be inherent or unalienable in our American church; rights may now be something that a person has to earn, and there is a list of behaviors and identities that earn rights and ones that render a human being ineligible to hold them. As a description of reality, this is nothing new; there have always been people whose rights were not recognized in America because of who they were, what they believed, or how they behaved. But for nearly two and a half centuries, the people of the United States still made the outlandish claim that theirs was a church where salvation was available to everyone, even when their laws and behavior did not reflect the requirements of that presumption. And on November 8, after fifteen years of living in a state of dull, but continuous fear, the people of the United States brazenly turned to a reformer who told them that salvation is not universal; it is, rather, limited and subject to the whim of an arbitrary and angry God.

Catholics still haven't forgiven John Calvin and his followers for the paradigm shift they brought to Christianity nearly five hundred years ago when they embraced a theology of predestination. Notice that unlike Martin Luther, John Calvin has been conspicuously absent from Pope Francis's ecumenical overtures during this quincentennial of the Protestant Reformation. That's because there is no bridge of reconciliation between a theology of limited atonement and one of universal salvation. And I'm not sure there's any bridge, either, between a political posture that says rights are earned and one that says rights are part and parcel of what it is to be a human being. I worry, therefore, that this rupture we are witnessing in the American church may be something that no ecumenical impulse can heal.

So what, then, Religion and American Culture asks us to consider, can we do as scholars and teachers of American religion? The only answer I have is one that applies to anyone who teaches and writes about the history and culture of the United States, regardless of whether his or her focus is on religion or politics or poetry or film. It's one that I suspect some of my colleagues will themselves resist, as we've all been so many Luthers these past few decades, posting our criticisms of our American church on our own Wittenberg doors, outlining the ways in which our leaders have corrupted our church's foundation and taking it for granted that our students already understand what that foundation actually is. But as this election - and yes, even some of the heart-felt, but muddled protests against it-makes clear, our students do not understand what the founding theology of our American church actually is. Therefore, we need to provoke a revival of our American church's spirit. We need a Counter Reformation, if you will (minus the Spanish Inquisition, of course). 
Launching an American Contrareformatio will require us first to acknowledge that there is such a thing as an "American" church, something many of us in higher education have been reluctant to do these last few decades, partially because of our enthusiasm for multiculturalism and partially because of our justified, post-Vietnam era wariness of what happens when so-called American exceptionalism makes its way into the foreign policy sphere. If this election taught us anything, though, it's that denying the reality of the American church does not work. It exists, and American voters know it; they are simply profoundly illiterate when it comes to that church's narratives, history, doctrines, and rites.

We will then need to remind our students unapologetically that the founding principle of our American church — the principle that a critical mass of voters rejected on November 8 -is the most liberating "theology" of governance humanity has ever seen, regardless of how flawed and incomplete its execution has been. We will need to present this theology to our students as a precious and radical gift—one that is not exclusive to our church, of course, but one that has been essential to our church's development and progress. We will need to help them interrogate this theology of governance so that they can understand its requirements and embrace it as the best retardant humanity has for the incendiary reality that we are, perforce, social creatures with selfish natures and rapacious instincts.

We, the people who teach in the humanities and the social sciences, have done a very good job over the course of the last forty years or so of enumerating and exposing our American church's corruptions. We have been less good at explaining why those corruptions are corruptions-what has actually been polluted or betrayed by conventions such as segregation, redlining, legislated homophobia, cultural and economic imperialism, and the glass ceiling. I am struck by this reality all the time. My students are very good at identifying the many injustices in America, and some of them are even able to apply complicated theories of race and gender to these injustices, speaking with real authority and understanding about the "social construction of race" and the "disciplining of gendered bodies." But they are incapable of offering up a sophisticated understanding —or even a definition —of what justice actually is, be it in an American or a universal context. They know we have fallen, but they don't understand what we have fallen from.

In posting our theses, I fear we have helped to create two phenomena, both of which contributed to the paradigm shift we witnessed in our American church this election. The first phenomenon-the one with the more obvious connection to the paradigm shift—was very 
much on display at Trump's rallies in the lead-up to his election. We heard it from his supporters when they praised him for "telling it like it is" and for not succumbing to "political correctness" (a term that hadn't been prominent in our national discourse since the late 1990s). These voters clearly rejected academia's focus on the experiences of women, gays, and racial, religious, and ethnic minorities-in part because they had an unsophisticated, incomplete, or even incorrect understanding of what America's founding theology was and what it required of them (I say "in part," because I think Richard Rorty's 1998 observation that academics have been unwilling to set up programs in "Trailer-Park Studies," even as they have established majors in "Queer Studies," also bears some consideration if we are to understand why so many Americans are rejecting what the academy has been doing).

The voters who were unoffended by the tone and content of Donald Trump's campaign failed to understand that the exercise of "virtue" (to use a word favored by the Founders) is an essential rite in any church founded upon a theology of unalienable rights. They did not recognize the obligations that come with membership in our American church-and that's partially because we, their teachers, failed to convey the essential nature of these obligations to them. We either assumed our students already understood the requirements of a free society-and went straight to the litany of corruptions of our American church - or we designed courses with reading lists and titles that, to be blunt, were never meant to capture the attention of any students who were not already among the converted. The fact that most of us who read this journal work with college students does not absolve us from some responsibility for the ignorance that made Donald Trump possible; more college-educated whites, after all, voted for the Republican candidate than for Hillary Clinton and Jill Stein combined.

The other phenomenon I fear we may have helped to create was at the heart of a gut-wrenching video that made the social media rounds last year. It was of an African American student at Yale who seemed to be condemning the sins of cultural appropriation-but was, I think, actually expressing her complete despair over the realization that there was no place for her in the American church because (she'd been taught) that the church's theological foundation was one of racism, sexism, and imperialism, rather than inherent and unalienable rights. As we have seen, ignorance of our church's founding theology can feed a tyrannical impulse. But a posture that says the founding theology is and always has been rotten to the core has the potential to breed nihilism-especially when that posture is combined with the very real experiences our students have with racism, sexism, 
and other forms of marginalization that are physically, emotionally, or rhetorically violent. Nihilism can be even more destructive to the human spirit than tyranny.

As angry as he was at times, Frederick Douglass rejected the notion that America's founding theology was rotten to the core precisely because he understood how corrosive and counterproductive that notion was. In his "What to the Slave Is the Fourth of July" speech-a brilliant jeremiad that never fails to move my students when I teach it in class - he made his case against slavery by appealing to four sources of authority: the Bible, the Declaration of Independence, the U.S. Constitution, and American identity itself. "How should I look to-day, in the presence of Americans," he asked his audience in Rochester, New York, "to show that men have a natural right to freedom?" To make such a case to a group of Americans "would be to make myself ridiculous, and to offer an insult to your understanding." The American people, after all, already knew that all human beings had a natural right to freedom. "You have already declared it," Douglass reminded his listenersbefore launching into what I believe still stands as one of the most stinging indictments of our American church the world has ever seen, one that was far more penetrating than anything Martin Luther ever aimed at the sixteenth-century Roman Curia. The indictment's sting derives from Douglass's understanding of and reverence for his American church's theological foundation.

I've said some controversial things in this postelection rumination. If I have represented our work as teachers of the American experience in a caricaturized way (as I know I have to some degree), I would ask the reader's indulgence in light of that context. I would also ask any reader who's made it this far to give some serious thought to what I have suggested here.

Two years ago, I began teaching the Declaration of Independence in my course entitled "Religion in American Life." It's something I'd never done before, but one day while reading over that document, a set of questions occurred to me-questions that I am embarrassed to admit in this forum had never occurred to me before: Was Thomas Jefferson being lazy when he wrote that all human beings were "created equal ... endowed by their Creator with certain unalienable rights"? Was God just an easy way for him to make his argument? Or was God essential to his argument-an argument that, let's face it, is belied every day by our own experiences with people who are clearly smarter, faster, or stronger than we are? Is it even possible to make such a ridiculous claim without an appeal to God? What are the origins of natural rights, and can there be natural rights in a system that has no God? 
I now ask my students to grapple with these difficult questions in a unit that considers the role religious belief has played in defining and developing American understandings of freedom. At various points throughout the semester, then-after they've encountered Emerson or Thoreau or Douglass or Rauschenbusch or King-I provoke my students to consider the requirements of life in a free society and how religious belief has helped or hindered Americans in their quest to meet those requirements (we consider the question after reading Thornton Stringfellow's pro-slavery sermons, too).

Perhaps I need to find a way to do more of this kind of teaching. Maybe we all do. We need to remind ourselves that although many of our students come to us rich with experience, that experience is not the same thing as understanding. It's our obligation to provide our students with tools that will enable them to achieve an understanding that is more than just honest or "awakened." That understanding must also be productive.

We need to remember that we have an obligation to teach all students about the rites and narratives and doctrines that animate our American church-not just the students who've already had their conversion experiences (or think they've already had their conversion experiences). We need to do a better job of figuring out what moves all of the students who attend our schools, regardless of whether those students are gay or straight, male or female, black or white, rich or poor, devout or irreligious, urban or rural, liberal or conservative, or anything in-between. Once we have figured that out, we need to design courses deliberately to attract everyone in this panoply-which will not, of course, avoid the difficulties that come with any serious interrogation of what it means to be an American.

We need to be more like Lin-Manuel Miranda. The genius of his Hamilton is that the production does what Frederick Douglass's speech did (without alienating anyone who just wanted some hot dogs and sparklers at a Fourth of July picnic in upstate New York). It shows us all how extraordinary America's founding theology of governance is by reminding us of what that theology demands from us. And it does so in a way that makes us sing.

\section{Wes Markofski}

Between the Christianity of this land, and the Christianity of Christ, I recognize the widest possible difference-so wide, that to receive the one as good, pure, and holy, is of necessity to reject the other as bad, corrupt, and wicked. To be the friend of the one, is of necessity to be the enemy of the other. 
Thus spoke Frederick Douglass in 1845, condemning the "corrupt, slaveholding, women-whipping, cradle-plundering, partial and hypocritical Christianity of this land." For many women and people of color across the United States-both religious and not-the night of November 8, 2016, unfolded like a bad dream, a painful reminder of this nation's incomplete and arduous struggle to expand the circle of rights, respect, and full civil incorporation to all Americans. Many white progressives-both religious and not-were likewise dismayed. They were joined by a vocal minority of white evangelical leaders across the political and demographic spectrum-young and old, progressive and conservative, female and male, northern and southern - who forcefully made the evangelical case against Trump, to no avail. "This is what it looks like when you sell your soul for a bowl of Trump," thundered Ed Stetzer-executive director of the Billy Graham Center for Evangelism at Wheaton College-at his fellow evangelicals in the flagship periodical Christianity Today. "He is," said Andy Crouch, executive editor of the same periodical, "the very embodiment of what the Bible calls a fool." Despite their many differences, what these people shared with one another-and with many scholars, pollsters, and pundits across the country-was a combined sense of shock and dismay that so many of their fellow Americans-or fellow evangelicals-could vote for such a candidate as Trump in the year 2016.

But should we have been so surprised? According to early exit polls, white evangelicals supported Trump at approximately the same level they have supported Republican party presidential candidates for nearly two decades. Though somewhat weakened compared to their heyday, old guard Christian Right organizations and leaders continued to express univocal support for Trump throughout the campaign, effectively mobilizing thousands of churches and hundreds of thousands of evangelicals to the polls. High profile white evangelical and charismatic megachurch pastors, church leaders, and televangelists joined Trump's "evangelical advisory board" and broadcast their support daily across conservative and religious airwaves, websites, church pews, and social media platforms. Though initially not their preferred candidate, evangelicals did not reject Trump during his unlikely ascent to the top of the Republican party primaries despite ample opportunity to do so. And no matter how distasteful to some, once Trump became the Republican party nominee, conservative evangelicals' longstanding obsession with Supreme Court nominations-and extreme animus towards the Clintons, President Obama, and the Democratic party coalition more generally-ensured that large swaths of white evangelical voters would "come home" in the end, as Mike Pence pleaded, to the party faithful. 
The historical and social scientific literature on white evangelical Christianity in the United States gives us more reason not to be surprised. Nathan Hatch's The Democratization of American Christianity points to evangelicalism's roots in the anti-establishment, mass-based religious populism of the early American republic. George Marsden's Fundamentalism and American Culture notes the anti-elite, anti-intellectual southern populist expansion of fundamentalist Protestantism's struggle against modernism in the 1920s. Mark Noll (1995) lays out the endemic anti-intellectualist and populist character of varieties of American evangelicalism. Darren Dochuck (2010) traces the midcentury spread of "plain folk religion" and conservative evangelical politics across the Bible and Sun Belts, while Charles Marsh (1997) chronicles white evangelical antagonism and indifference toward the black civil rights movement of the 1950s and 1960s. And in White Protestant Nation, Allan Lichtman traces the ethnoreligious and probusiness engines of American conservatism throughout the twentieth century, culminating in the rise of Christian Right "culture war" politics and Republican party consolidation of white Protestant voters since the 1980s.

Moving from history to the social sciences, James Hunter (1987, 1991) takes for granted white evangelical political conservatism while developing his "culture war" thesis. Political scientists and sociologists (Lipset and Raab, 1978, 1981; Wald et al., 1989) account for the rise of the Christian Right and other mass-based moral reform movements via a "status politics model" emphasizing white conservative Protestant resentment and nostalgia for a lost Christian past. Robert Jones updates the argument in The End of White Christian America and other writings, arguing that white evangelicals have become "nostalgia voters" as much as "values voters," while other recent work continues to show the powerful effects of moral traditionalism, Republican partisan identification, regional residence, and lower levels of education on white evangelical voting behavior (e.g., Brint and Abrutyn, 2010; Goren and Chapp, forthcoming; Silk and Walsh, 2008). And in The Politics of Evangelical Identity and other work, Lydia Bean underscores grassroots evangelicals' deeply integrated ethnoreligious and conservative political identity as a potent and durable source of Republican party identification among white American evangelicals that differs significantly from Canadian evangelicals.

Given this mass of scholarship, one might ask, why all the shock and dismay about white evangelicals' overwhelming support for Trump? Is this not what we should have expected all along?

There are at least two reasons for the surprise. One is that the election of Trump appears to many as a failure of conservative 
evangelical political engagement on its own terms. Scores of prominent conservative evangelical leaders warned against the dire consequences of an evangelical-fueled Trump presidency for the integrity and public witness of the evangelical church in America. They noted the hypocrisy of timeworn conservative evangelical screeds against the "corruption," "lying," personal character, and sexual ethics of the Clinton era while justifying and ignoring Trump's far greater problems in these arenas (Crouch, 2016; Gerson, 2016; Noble, 2016). They condemned Trump's transparent egoism and will-to-power, his praise of authoritarian strongmen and disregard for democratic norms, and his verbal disdain for women, the disabled, the weak, and the marginalized as unchristian and un-American (Beaty, 2016; Erickson, 2016). Claiming, "racial justice and reconciliation are now core for the [evangelical] movement," they lamented the divisive racial rhetoric against Mexican and Muslim immigrants and other people of color espoused by Trump and his emboldened Alt-Right supporters (Cox and Moore, 2016; Erickson, 2016; Galli, 2016). None of it mattered. One lesson of the 2016 election is that no matter who wins the Republican party presidential nomination, a significant majority of white evangelicals will find reason to vote for him.

This brings us to the second reason for surprise. The rise of oppositional voices to Christian Right hegemony in the field of American evangelicalism, and the increased visibility and attention mainstream media has given these voices, reflects a trend in recent scholarship on American evangelicalism tracing back to Christian Smith's (1998, 2000) landmark work in the field. In Christian America? What Evangelicals Really Want, Smith warned against viewing evangelicals as a static, homogeneous, ideologically consistent, vertically integrated, politically conservative monolith. Instead, Smith argued, American evangelicalism must be viewed as a messy, internally diverse, ideologically contested religious umbrella rife with political and religious anomalies, inconsistencies, and internal contradictions. In particular, Smith warned against the "monolithic religious bloc fallacy," that evangelicals constituted a single monolithic political-religious bloc, and against the "representative elite fallacy," that ordinary evangelicals shared the religious and political viewpoints of their purported spokespersons on the Christian Right.

After years of ignoring this internal diversity and contestation within the American evangelical field, recent scholarly work has been paying more attention. Molly Worthen (2013) and David Swartz (2012) explore the arguments and inner workings of oppositional perspectives within the evangelical right and evangelical left, respectively. James Bielo (2011) and others (Marti and Ganiel, 2014) chronicle the 
"emerging church" movement and its oppositional standpoints vis-àvis conservative and megachurch evangelicalism among younger evangelicals. In The New Evangelical Social Engagement, Steensland and Goff (2014) compile a series of essays on progressive and centrist evangelical social activism opposed to the narrow political and social vision of the conservative evangelical right. Numerous studies note younger evangelicals' (modest) movement away from a range of conservative evangelical political attitudes and identities (Bean and Martinez, 2014; Danielsen, 2013; Farrell, 2011; Pelz and Smidt, 2015; Smith and Johnson, 2010). In New Monasticism and the Transformation of American Evangelicalism, I explore ethnographically new monastic evangelicalism and locate it analytically within the larger field of American evangelicalism, which I define in Bourdieusian terms as an internally diverse and contestatory "field of agreement and struggle between agents holding competing visions of the legitimate representation of biblical Christianity in the United States." Newer work (Markofski, 2015) explores varieties of progressive evangelical public engagement in Portland, Los Angeles, Atlanta, and Boston. In each of these cases, scholars probe and problematize the reduction of American evangelicalism to conservative partisan politics.

Were we wrong to do so? Does the 2016 election signal a return of the monolith, a freshly justified interpretation of white evangelical America as the Republican party at prayer?

Yes, and no. One of the ironic lessons of this campaign season has been a reinforcement, rather than repudiation, of Smith's "representative elite fallacy," this time in the opposite direction. Smith chastised scholars and media pundits for taking the standpoints of Christian Right leaders as representative of ordinary evangelicals. In this election, evangelical leaders across the liberal-conservative spectrum voiced significant opposition to Trump; in true populist fashion, ordinary evangelicals ignored them and voted for Trump anyway.

What then of the monolithic bloc fallacy? Here it gets tricky. The internal diversity and contestation highlighted in recent studies of American evangelicalism is empirically real, politically significant, and theoretically vital to understanding the religious and political standpoints of American evangelicals and how those standpoints are reproduced and transformed. At the same time, this election reminds us of the deep entanglement of traditional white conservative Protestant religion with elements of patriarchy, probusiness populism, strict moral traditionalism, anti-intellectualism, xenophobia, and white Christian nationalism. It also reminds us that conservative politics and partisan political identification have become core elements of religious selfidentity among dominant expressions of evangelical Christianity in 
the United States, and that this core identity retains significant strength and durability beyond the vagaries of particular politicians, super PACs, election cycles, and immanent critique. Perhaps we need to begin distinguishing between "political evangelicalism" and "evangelicalism" in the same way we distinguish between "political Islam" and "Islam."

Perhaps we also need to take a more critical view of the racial boundaries and meanings of white evangelical believing, belonging, and behaving in the United States. Rather than viewing white American evangelical theological individualism as flowing from a race-neutral idiosyncratic biblical hermeneutic shaped by national context (Smith and Emerson, 2000), perhaps we need to consider more carefully arguments that American evangelical political theology is more deeply and perniciously racialized than has been frequently acknowledged (Bean, 2014; Edgell and Tranby, 2007; Tranby and Hartmann, 2014). We might make the same argument about dominant evangelical theological perspectives on gender. It is true that most evangelicals do not espouse explicitly racist perspectives and that discussions of racial injustice have made their way into mainstream American evangelical discourse. Too often, however, evangelical efforts to attend to problems of race and gender inequity have the decided appearance of being too little, too late, and too unreflexive about white American evangelical complicity in the establishment and reproduction of unequal social relations and structures across categories of difference.

What other lessons or future research directions might the 2016 election hold for scholars of American religion? One might be increased attention to struggles over the boundaries and definitions of what it means to be an evangelical Christian in the United States. Long before Trump, progressive and younger evangelical movements and individuals were wrestling deeply with whether or not to continue identifying as "evangelical" in light of its conservative political connotations. Increasingly, the answer has been no. Will 2016 increase the trickle of disaffecting evangelicals into a wider stream? If so, where will they go? What new movements and forms of Christianity in America might emerge in the age of Trump? Another might be heightened attention to the forms, processes, and effects of diverse expressions of politicization in the evangelical field. Political identities and position-takings (including apolitical or anti-political standpoints) already structure the evangelical field in significant ways; this is likely to increase in the days ahead.

We might also want to pay greater attention to distinctions and relations between "cosmopolitan" and "populist" evangelicals (Lindsay, 2007) as we investigate various aspects of evangelical 
political and religious belief, belonging, and behavior. This could involve some modest walking back of the ascendant "strong program" in the sociology of religion (Smilde and May, 2010) and concomitant refocusing on the social sources of varieties of religious expression in the United States. Finally, we might watch for new forms of resistance and emerging "coalitions of the dominated" that bring together evangelicals and others across race, gender, and religious difference in oppositional solidarity to real and perceived threats of the days ahead. In the unpredictable age of Trump, dissent and resistance may count among the few things we can predict with some certainty.

\section{Robert Orsi}

It has been a long time since "the white working class" has gotten as much attention as it did this past election season. "The white working class" has been invoked to account for the perversity of the electorate, for the seething tides of anger and resentment on which Trump rode to victory, and for the terrible ugliness of civic life in the United States in the past year. And it looks like "the white working class" is not going away any time soon. An editorial headline in the Washington Post on the morning after the election declared ominously, "How Trump Won: The Revenge of Working Class Whites." It appears we will all be dining for the next four years on the cold supper of "white working class" vengeance.

But who is this "white working class"? Although it was rarely if ever made explicit, the phrase "the white working class" as it was used during the election seemed mainly to refer to the descendants of the two great waves of European Catholic immigration to the United States, first from Ireland and Germany in the middle years of the nineteenth century, later from eastern and southern Europe in the late nineteenth and early twentieth centuries. (The third wave, in 1965, brought East and South Asian Catholics to the United States, among other people.) "White working class," in other words, means "white ethnic Catholic industrial working class." When national newspapers sent reporters "out" to wherever it was this "white working class" lived to learn what was on their minds-the "out" here underscoring just how distant elite journalism and journalists were from the population to which they were attributing such historical importance-these reporters nearly always made their way to a small city in the old rust belt, invariably describing it as once bustling but now grim and desolate, and to the kitchen table of an old ethnic Catholic couple. I could almost see the faded sepia print of "The Last Supper" hanging on the wall. 
My ninety-year-old father and I were watching the evening news together one night this past September when Trump appeared on the screen. "I know a dictator when I see one," my father said to me, "and he's a dictator." My father, who grew up under Mussolini, experienced Italy's descent into internal political violence, imperial adventurism, and international war; he is also one of the few survivors of a 1944 massacre of local townsmen and monks in a Tuscan Cistercian charterhouse by the SS. He spent the week before the election phoning and visiting various members of the family to plead with them not to vote for Trump but without much success. The majority of my relatives, as of Italian Americans in general, either failed to see in Trump what my father did or else saw it and approved and welcomed it. There were painful personal and domestic consequences to this political split between my father and other relatives. Two female cousins of mine who live near my father will no longer drop by to keep him company as they once did regularly because he refuses to fire the Peruvian woman who cleans his little apartment every two weeks. They seem to think that this kind and generous woman is part of what is keeping America from being great again.

Thus it is both as an Italian American from the working class and as a historian of American Catholicism that I approach the fact that white ethnic Catholics contributed so fundamentally to Trump's triumph. I want to use the opportunity of this commentary to think about why American Catholics in such numbers looked to Trump as the answer to whatever they thought their problems and the problems of the country were, and also as a case study in the dangers and promises of such an enterprise of critical examination of the lived experience of "the white working class." If we hope to make historical sense of this election, we are going to have to learn how to think about "the white working class" in its moral, social, and existential ambiguity, and in its fissiparous diversity; about how class works within families and religious communities, as well as in public life; and about the power of painful memories of class injustice to endure over generations and to shape current events.

The phrase "the white working class" implies the singularity of this demographic, as well as its boundedness-"the white working class" is out there-but the realities of social class in post-World War II American Catholicism are far more fractured, entangled, and unstable than this suggests, and it is this instability and this multiplicity of experience, memory, aspiration, and education, along with the nature of the work people do and what they earn, that has created the political dynamics that govern U.S. Catholicism today. The late sociologist Father Andrew Greeley argued that the majority of the contemporary 
descendants of European Catholic immigrants-the immigrants' children, grandchildren, and now very often great- and great-greatgrandchildren-are no longer blue collar. The economic and professional trajectory of American Catholics after World War II by his account has been steadily upwards, eventually almost equaling the achievement of American Jews and surpassing that of most American Protestants.

This confident narrative of the Catholic rise to social prominence in the United States, while a useful corrective, pays insufficient attention to variations within Catholicism, among Catholics, not only between ethnic groups but within families, churches, and neighborhoods. Social class is always relational; it draws from and contributes to diverse intersubjective and communal divisions and tensions, amplifying them and giving them a particular cast. For example, the daughters and granddaughters of eastern and southern European Catholic immigrants entered the postwar service economy before their male counterparts did so; younger women were educated for this new economy in "business" or secretarial schools; they did better within it; and, as a result, they dressed better than their fathers and brothers, were more knowledgeable and sophisticated about aspects of modern life that eluded the men, and they were practiced at speaking across social class. The results were intimately experienced gender and generational tensions and resentments that were often quite bitter and corrosive. The realities of social class within Catholicism were explosively gendered and aged, contributing to relationships haunted by doubts, fears, and shame across generations and sexes. Without generalizing about male/female relations in any community, the historical reality of this gendered divergence may help explain why so many "white working class" men were not offended but compelled by Trump's strangely 1950s/1960s perspectives on women as sexual objects and by his misogyny, why he was able to activate within "the white working class" a reaction of male hysteria.

The American media treated political divisions within families during and after the election as a kind of unfortunate by-product of the political sphere and offered counsel for getting along with potentially estranged friends and kin rather than political or historical analysis. Such a therapeutic approach fails to consider the possibility that fissures within families, among siblings, between generations, and so on, were already there and that voters used Trump as a device for articulating and exacerbating the most intimate internecine hostility. Trump widened but he did not create differences within families, which at least within Catholicism often run along the fault lines of class, with one family of several within a clan having made Greeley's 
upward trajectory but not another, one sibling, one generation, or one gender, but not others. It is important to keep in mind the asynchronous and multiple realities of class along with the unequal distribution of wealth and privilege within Catholicism when thinking about Trump's appeal to "the white working class."

Among the hidden injuries of class, in Jonathan Cobb and Richard Sennett's phrase are religious damages. Religion and class have been entwined in American Catholicism throughout the twentieth century, with consequences for how people have experienced the faith every day and often in the most difficult human circumstances, as well as for how they perceived the political sphere. Working class Catholics after the Second Vatican Council (1962-1965) often complained that decisions about how they would pray, for example, what they could and could not do in church, and whether there would be a statue of the Blessed Mother for them to address their petitions were all made by newly empowered and educated middleand upper-class lay elites in alliance with priests who would rather associate with prosperous than with working-class parishioners. Profound differences regarding matters of practice, politics, and ethics follow class lines within Catholic parishes, regarding abortion, for example, or social justice, as in the later 1960s, when public dissent within Catholic communities about Vietnam generally followed divisions of social class.

None of this is meant to imply that all blue collar Catholics were ardently in favor of the war in Southeast Asia or that all middleand upper-class Catholics are pro-choice. It is to say, though, that disagreements about religious matters were always experienced and expressed within a community that was fractured by economic class and that such matters almost always took on class dimensions. This did not escape the notice of Catholics themselves at various times between the 1940s and today, as their letters to the editors of various popular periodicals indicate. Working-class Catholics who suddenly discovered that the cherished practice of saying the rosary beside a loved one's coffin was now strongly discouraged as being nonbiblical, as happened after the Second Vatican Council, or that white not black was now the color of Catholic mourning for reasons that made sense to a learned liturgist but to no one else, were experiencing the world as out of their control, of having to abide by decisions in which they had no say. I believe that when Trump's followers proclaim that he permits them to say things they have been unable to say before, they are making a racial comment, meaning essentially that they are now able to say things about black and brown people they could not say before. But I don't think this is all they are saying. They are also calling for retaking 
their voices back from elites in many different areas of experience, including religion.

In a prescient 1969 article in New York Magazine, journalist Pete Hamill identified what he named the new "American demonology." "Here comes the murderous rabble," Hamill wrote, "fat, well-fed bigoted, ignorant, an army of beer-soaked Irishmen, violence-loving Italians, hate-filled Poles, Lithuanians and Hungarians (they are never referred to as Americans)." The lived realities of working-class life had been the subject of attentive and close-grained study by sociologists and anthropologists in the 1950s and early 1960s. There was no question then of sending a reporter "out" for one or two short conversations to be followed by a profile of the working class. Included in this scholarship were William Whyte's Street-Corner Society (1955), Herbert Gans's Urban Villagers (1962), Mirra Komarovsky's BlueCollar Marriage (1964), and Cobb and Sennett's The Hidden Injuries of Class (1972). By the time Hamill was writing, however, working-class Catholics (Hamill never identifies them religiously, but this association is evident from the groups he lists) had become the prototypical hardhats, beating up young people protesting the Vietnam War, mindlessly patriotic, and from this point forward intellectual curiosity about "the white working class" dried up because everything was already always known about them and there was nothing to be discovered.

Hamill warned his middle- and upper-class readers, "All over New York City tonight, in places like Inwood, South Brooklyn, Corona, East Flatbush and Bay Ridge, men are standing around saloons darkly talking about their grievances, and even more darkly about possible remedies." With his catalogue of vile stereotypes of working people, Hamill was mocking the prejudices of his middleand upper-class liberal readers, but in his prophecy of the coming working-class apocalypse he seems suddenly to shift sides, offering a vision of bitter, resentful, and excluded workers considering "remedies" too awful to specify. In any event, Hamill reminds us that the phrase "working class" has always carried an excess of terror, hinting at the threat of violence, neighborhood, national, domestic. This year's "white working class" bears the imprint of this history and its excess. But, who today would talk about the descendants of white ethnic Catholics as beery, violence prone, fat, and bigoted? Let me remind readers that "American Catholicism" is asynchronous, poly-spatial, and multiply fractured by class within families, in parishes, and in public life.

This raises the question of working-class memory, of the way the hidden injuries of class remains across generations, and requires a history of remembering. Consider the story of American cities after 
World War II. White ethnic Catholics were intimately and directly caught up in all the major dislocations of the times. The great migration northward of southern African Americans before, during, and after the war was, among other things, the epic and tragic encounter of black people and white Catholics. White ethnic Catholics erroneously but passionately recall this as a time when they lost their place in the cities. Internecine conflict among Catholics was likewise fierce in this time and in these places. Italian Americans in New Haven, New York, Chicago, Detroit, and elsewhere felt betrayed by Irish Catholic politicians who in league with the federal government introduced disastrous urban renewal plans that entailed the destruction of Italian (not Irish) working-class neighborhoods, usually with promises that dispersed residents might return which were never kept. Irish Catholics in South Boston, Chicago, and elsewhere fiercely resisted the integration of schools (while other Irish Catholics championed civil rights), which they believed was being imposed on them by elites who knew nothing about their everyday lives.

All of this happened a long time ago, yet we should not fail to reckon with the enduring power of the memory of what was experienced as class injustice among "the white working class." American citizens, including historians, are right to deplore the redlining of neighborhoods to keep out African Americans; the complicity of parish priests in pressuring their parishioners not to sell their homes to black people under pain of sin; and the street violence against black families who dared to move into white Catholic neighborhoods. But we need not approve in order to attend to the hidden injuries left by this period in "the white working class," the grief that inchoately mixed with the rage and racism, the desolate feeling of having lost a world, which gets compounded two decades later with the closing down of parishes based on the decisions, once again, made by an absent and unaccountable elite, an elite, moreover, that had just been revealed as caring so little for the children in "white working-class" communities as to put among them priests with a history of sexually abusing young people. The injuries of class are as much a matter of memory as they are of contemporary experience, and as ugly as much of this history was, the memory of it bears careful scrutiny for its enduring pain. The half-life of working-class misery is long. To speak of "the white working class" is to speak of people who remember (with all the construction, distortion, and displacement that remembering entails) the real and imagined pain, social, economic, and religious, of the past five decades, and who have passed on this memory to their children and grandchildren.

So what good is all of this analysis? Trump's election is at once both transparent and opaque, and it will take generations to pick apart 
all the many pieces of American experience and memory that contributed to it. I've chosen one piece to examine, "the white working class," to see if by giving a fuller account of the genealogy of the phrase, of what it allows us to see and what it covers over, one dimension of Trump's triumph might be illuminated. Social class as I've discussed it here is at once about realities in the present and in the past, in experience and in memory, that to its injuries adhere other grievances and pain, that it is as much a religious as a social and economic reality. It is not enough to say that "the white working class" and its descendants are wrong to blame people of color for the woes that befell them in the past decades; it is necessary instead to piece out where that idea comes from, what else it articulates, how it has endured, and what it may teach us about how to rebuild a civil society that includes this "white working class" that has felt so long excluded. It is useful to recognize how marginal "the white working class" became to American life, not just economically, since the late 1960s and 1970s, when white workers were cast as a brutish horde of barbarians threatening the gates of American civilization.

Trump is a catalyzing figure. Using graphic, obscene, and emotionally charged language, he speaks to those places where people's intimate experience - sexual, existential, religious, psychologicalintersects with the public sphere and the political imaginary. By unpacking and disentangling the deceptively singular "white working class" it becomes clearer how Trump pressed on its fissures and faultlines, conscious and unconscious, in such a way that these were activated as a political force. And by showing how elemental these are, how Trump's language taps into the emotions, relationships, fears, memories, hatred, and desires that have been sinking roots for decades, we will understand that "the white working class" is not motivated by economic concern alone or even primarily. Essential as the economic is, the insistence on this in postmortems of the election seems to me to be a way of comforting and reassuring ourselves.

The public sphere is awash right now in emotions, grievances, fears, resentments, and memories, rooted in the realities of social class, making it extremely difficult if not impossible to find ways of speaking to each other across "political" divisions, reasonably and pragmatically, in order to meet pressing problems. The challenge is to follow the emotions back to their historical, religious, and psychological grounds, as I have tried to do here with one section of the population; to examine them for what they have to teach us about the hidden injuries that underwrote this election; and then to see if the public sphere may be repaired. None of this is easy. But without it we are doomed to cycles of grievance and misunderstanding that benefit only the dreams of autocrats. 


\section{Jerry Z. Park and James Clark Davidson}

If we can narrow down the main stories concerning religion in the electorate, we might say that the American public was reckoning with the intersecting ideologies that make up white American Christian (ist) patriarchalism on the one hand and American multicultural liberalism on the other. In this essay we argue that these two frames help situate American religion in its multifaceted forms and go a long way in explaining the decisions of many that seem counterintuitive to outsiders. This also explains why the arguments that cast blame on certain religious subgroups' hypocrisy is insufficient as these positions rely on coalitions of religious and nonreligious groups that have overlapping and conflicting visions and social priorities.

\section{White American Christianist Patriarchalism}

Same as It ever Was: White Conservative Protestants and Catholics (Still) Together

Religious change was in the air in 2016, at least if one were to borrow from some of the headline news that evoked images of a dying white American Christianity. Others called the term "evangelical" meaningless in the face of statistics that presented a paradoxical support for a racist, sexist demagogue that failed at every turn to represent the values of tolerance, empathy, and compassion which some Christians attribute to their founding leader. But a closer look at the voter turnouts, survey results on religion and politics, and the rationales provided by anecdotes of white evangelical Trump voters shows that very little has changed with the exception of one critical shift.

Despite the growing percentage of nonaffiliated Americans, American evangelicalism has remained relatively stable at about a quarter of the electorate. This is quite large but not enough to win an election. Indeed, there was never a time in the past thirty years from the Moral Majority to the Religious Right and the Christian Right in which there was a majority of American evangelicals. White evangelicals and white conservative Catholics who shared political concerns formed coalitions which certainly added to the number of GOP-leaning voters but again not large enough for victory. In the old culture wars framing, these culturally orthodox relied on loyal turnout. On that count, the 2016 election showed no noticeable difference among white evangelicals than in previous elections. Progressive white and nonwhite evangelical lamentations about the crisis of Christianity sometimes overstate the reality that many white evangelicals prioritize certain issues in the culture wars 
framework far above others. In this sense, evangelical religion is not anything different from what we have seen before.

So were the criticisms completely off base? Little noticed in the social media newsfeed of many was a notable and dramatic shift on one particular issue that has long been a feature of the Christian Right. A recent survey found a sizeable shift in expectations on the public positions and private behavior of political figures. For years, polls revealed that white evangelicals were among the least likely groups to support an immoral person as an exemplary leader. But in the lead up to the 2016 presidential election, white evangelicals became the group most likely to say they can separate the personal immorality of a candidate from ethical leadership. In the past five years, the rate of evangelicals approving of this distinction in a leader went from less than a third to nearly three-quarters, an increase of more than forty points. This shift helps partially explain how white evangelicals justified support of a GOP candidate with evident character flaws. The new willingness to separate personal failings from public leadership makes it much easier to accept such a personally flawed candidate. Notably, too, American attitudes generally trended in this direction, as nearly all groups saw a small but marked increase. So was this a one-time rationalization based on political expediency or a signal change?

\section{Religion and the Alt-Right}

Many news reports repeatedly mentioned an emerging constituency labeled the Alt-Right. Missing from these was the place of religion within this group. Many of the estimated four million members of the Alt-Right are anti-Semitic Nones, with a small but significant group of neopagans. By neopagan we specifically refer to an agglomeration of Nordic and English pagan mythology that provides a cosmological narrative for their beliefs about white supremacy. Notably, this belief is held individually and privately with only occasional instances of collective religious gathering (not unlike ancestral veneration practiced by some Asian Americans). Ideologically, many Alt-Righters consider Christianity as an impediment to their movement. The Alt-Right emphasizes nationalism and tribalism which is undermined by the general equality and human rights principles that many mainstream Christians espouse. Tolerance and equality for all is antithetical to their belief system. "Excessive" Christian charity results in cultural Marxism and the downfall of the West and, thus, white identity.

This is not to say there aren't Christians in the movement. There is a vocal minority that seeks to reconcile Christianity with the 
Alt-Right, similar to sociologist Phil Gorski's distinction between Christianism and Christianity. They claim God's favor is what has made the white person superior. Christianity is foundational in western culture and, therefore, whiteness. They claim the Bible was written specifically for whites to encourage the growth and success of white culture. While most evangelicals may not agree with these assertions, they do align with the Alt-Right's promotion of nationalism and antigay traditional family stances. These positions are typically supported by cherry picking of scientific texts and an ever-growing literature of Alt-Right pseudoscience.

\section{Jews and the GOP}

Jewish Americans have been at odds with both parties given the complex interests that stand as the primary concerns and priorities for this constituency. Preservation and protection of the nation of Israel has been the strong card in the GOP hand to woo Jewish voters. But with the rise of the Alt-Right and their noted anti-Semitism, it remains to be seen whether these conservative Jewish voters will remain committed to the GOP. Indeed, Jews joined with Muslims in receiving greater discrimination after the election both in individual assaults and defacement of synagogues. How will conservative (largely Orthodox) Jews comfortably inhabit the same space as the anti-Semitic Alt-Right? To the extent that politically conservative Jews emphasize ethno-religious self-preservation symbolized in the nation of Israel, the future is indeed ambiguous when some of their influential fellow conservatives view them as a major threat to their way of life.

\section{Nonwhite Religious Conservatives?}

As the data roll in, we are seeing hints that nonwhite evangelicals are far more ambivalent about the GOP and yet not overly fond of the DNC. Results from the National Asian American Survey in 2012 and the Pew Asian American Survey (2012) suggest that Asian American evangelicals favored the DNC candidate over the GOP one. However, the minority of Asian and Latino evangelicals supporting the GOP was much larger than African American evangelicals. Preliminary analysis from the 2016 National Asian American Survey confirms this pattern again. Similar to Orthodox Jews, nonwhite evangelicals face a significant dilemma where the Alt-Right's influence overshadows white evangelical interests, and by extension their disdain for nonwhites further marginalizes them. With nonwhite evangelicals growing in number, at what point will their numbers turn into influence? Or will they remain perpetually sidelined? 
In sum, the combined presence of white Protestant evangelical and Catholic voters, the nonaffiliated/neopagan Alt-Right and Christianist Alt-Right, conservative Jews, and some nonwhite conservative Christians in the GOP camp of the future should lend itself to new avenues of scholarly investigation regarding how these constituencies view one another and the direction of the party they support. The Alt-Right is the group that creates the most tension and incongruence with religious conservatives, and their emerging influential presence is certain to alter the status quo.

\section{American Multicultural Liberalism}

If the GOP seems to be a home for conservative white Christians, white neopagan/atheist and Christian nationalists, some Jews and a minority of nonwhite conservative Christians, the Democratic party seems to be a curious catch-all of others, many of whom likely have deep disagreements with one another. For example, the majority of religiously nonaffiliated Americans are Democrat, a sizeable minority of evangelicals and conservative Catholics are also Democrat (although a much smaller fraction of them voted in 2016), as are most secular and Reform Jews, mainline Protestants, liberal Catholics, nonwhite evangelical and conservative Catholics, Muslims, Sikhs, Hindus, and Buddhists. What holds them together might be described as an American multicultural liberalism that champions identification with a religiously inclusive and tolerant vision of America that celebrates difference and ideally provides full and equal protection of all groups (i.e., ones not reputed to be intolerant and exclusive). While maintaining unity has been a perennial challenge for the DNC, to what extent did religious difference possibly play in the 2016 election and what might lie ahead for the DNC?

\section{Mainline Protestants, Progressive Evangelicals, and Catholics}

The media often frame the political actions and discussions of the Religious Right as those of religious people more broadly. The data tell a different story. There are many progressives within all religious traditions. Historians have noted in the late nineteenth and early twentieth centuries the decoupling of social justice and personal piety that once characterized American Protestantism. Today, the Protestant mainline (exemplified by Hillary Clinton's Methodist background) largely has embraced modernism and retained a quiet influence on social justice related matters. Paradoxically, a slight majority of white mainliners voted for Trump, perhaps reflecting a disjuncture between the liberal leadership and the members in the pews. 
While conservatives make up the majority of evangelicals, there is a social/political progressive wing that is still conservative by most measures of religiosity. Morally, they place a greater emphasis on social justice, compassion, and avoiding judgment of others. While conservative evangelicals are motivated by abortion and gay marriage policies, progressive evangelicals are concerned with racism and sexism. They tend to lean Democratic or Independent. They tend to be younger and less white than their conservative counterparts. They often discuss conservative evangelicals as potentially dangerous fundamentalists, while they are in turn caricatured by their conservative evangelical counterparts as godless liberals. The moderate middle appears to be shrinking or is, at the very least, silent. The questions are whether this cleavage is growing, and will progressive evangelicals continue to exist in a group that is growing more partisan? For example, recently the Baptist General Convention of Texas took the unprecedented move to expel LGBT-affirming churches, reversing decades of Baptist congregational autonomy; in addition, the parachurch evangelical college ministry Intervarsity Christian Fellowship has issued a vague statement that some read as a similar purging of LGBT advocates among its staff.

White Catholics also favored Trump by a slight majority, but the devil is in the details. Trump fared best among older white Catholics, but there was also a massive gender and race gap. Catholic women favored Clinton by a significant margin in nearly all demographic categories. Similarly, Hispanic Catholics strongly favored Clinton compared to Trump. These groups are younger, less white, and more female. Yet this coalition is not enough to swing the white males who voted for Trump at a rate approaching the white evangelical vote.

\section{Muslim Voters and the Religions of Brown Folk}

Despite being only a sliver of eligible voters, more Muslim voters registered to vote in 2016 than ever before. Donald Trump's calls to limit migration and to have a database of Muslims clearly motivated political action. In previous elections, most Muslims abstained from political participation. They cited interventionist foreign policies espoused by both political parties as difficult to support. They are a diverse group, most are fiscally conservative, profamily, and tough on crime. Polls indicate most Muslims (78 percent) voted for Bush in 2000. Post 9/11, conservative anti-Muslim rhetoric and expansion of wars in the Middle East pushed Muslims toward voting Democratic. Clinton was problematic for them as she was seen as too right wing and a war hawk. Despite these reservations, most Muslims voted for Clinton, but many would 
say their vote was against Trump. Will they stay motivated to participate in the future? Will these generally conservative religious voters continue to be pushed to vote for the liberal candidate?

Other minority religions have been strong supporters of the Democrat party. Hindus, Jains, and Buddhists all face a similar dilemma. Dharmic religions often include pillars that are difficult to reconcile with the American political system. They tend to be proenvironment, prolife, propersonal responsibility, antideath penalty, and antiviolence. No party captures these values, so many are left with a difficult decision. Many of these voters choose simply to stay home rather than participate in a system that doesn't reflect them, but when they do go to the polls, they cast votes for the Democratic candidate. While they are a small minority of the electorate, can Democrats motivate them to come out to the polls in greater numbers, or do their left leaning libertarian views eventually lead them to support conservative candidates?

\section{Democratic Jewish Voters}

The Jewish electorate supported the Democratic candidate by a large margin. Of those who supported Trump, they cited concern over the stability and sovereignty of Israel as their main concern. Those who voted for Clinton expressed greater concern for the poor, support for organized labor, and other pillars of the typical American liberal agenda. Many sincerely believe that their liberalism is codified in Jewish law and the heritage of Jewish values. But were this the case, we'd expect that the most liberal among them would be the Orthodox community. The reality is quite the opposite, with Orthodox followers expressing the highest levels of support for conservatism among the Jewish community. The Orthodox often discount their liberal counterparts as "secular Jews" and their religion as "the Democratic party with holidays thrown in."

During the primary season, many Jewish voters supported Bernie Sanders. The selection of Hillary Clinton as the nominee (the more conservative choice) was a disappointment for many in the liberal Jewish wing. Sanders, a Jew himself, was emblematic of their movement. His policies were more secular and neosocialist in comparison to Clinton's understanding of traditional, moderate institutional power. Of note, Sanders was less sympathetic to the state of Israel than Clinton. Why, then, his high levels of support? Similar to white mainline Protestants, non-Orthodox American Jews view their faith in inclusive and less sectarian ways. To some extent, protection of Israel is a lower priority in favor of the more immediate concerns of inequality, poverty, and 
racism, even Islamophobia, occurring in their midst. And yet, cracks may be beginning to show. Clinton didn't do as well as Obama in attracting the Jewish vote, there is concern over the party courting the Muslim vote, as well as hints of a growing undercurrent of antiSemitism in the political left. Do these potential areas of strain weaken the commitment to the Democratic party? If conservatives continue to court the Jewish vote through pro-Israel policies and are able to suppress anti-Semitic strains in their own party, might we see a shift in Jewish political alignments, or do they remain solid supporters of the liberal candidate?

\section{The Religious Unaffiliated Majority}

The religious Nones (consisting of atheists, agnostics, and the religiously unaffiliated) is the fastest growing group in the United States. They show liberal tendencies and preference for the Democrats with around two out of three consistently voting for the Democratic candidate in the past few presidential elections. Some have theorized that this group is made of religious refugees. Most are former church members who have grown uncomfortable with the alignment of religious groups with political parties. This disillusionment appears to extend not just to the public role of religion in politics but to political participation in general. Making up around a quarter of eligible voters, many simply do not vote. When they do vote, this group represents some of the strongest support for third party candidates.

If a common feature of the Nones is disappointment with establishment institutions, predicting future political behavior is challenging. They are nearly the size of the white evangelical population and growing. Can they be motivated to participate, and will they become a strong bloc for the Democrats? Or, if secularization theorists are to be believed, will the perpetual move away from organized religion cause this group to begin to reflect the population as whole and, thus, lose their liberal leanings? To that matter, as this group grows and has children of their own, will the identity of a None change? If one is raised in a home with no religion and doesn't have one to leave, will institutional apathy still exist?

In sum, the Democratic party, with its numerous religious (and nonaffiliated) constituencies, has a challenging road ahead. On the international scene can they show support for the nation of Israel without alienating Muslim Americans? Will atheist Nones continue to tolerate participation in a party that houses progressive-minded devout Protestants and Catholics (whose religion is often stereotyped as irrational, intolerant, and antiscientific)? 


\section{The Road Ahead: Deinstitutional Religious Diversity}

Since neither major party has an identifiable bloc that can easily direct its respective platforms, we can only be certain that leaders in both wings have their work cut out for them. This has always been the case but was perhaps less notable previously when white non-Hispanic Americans posed a supermajority. That majority status is quickly dwindling, and, as such, the religious configuration of the country is also changing in some unexpected ways. It is the case that the electorate is comprised of more religious minority groups, but the biggest constituency (if we can call it that) is made up of those who have disaffiliated from institutional religion. Most of these are Independent or lean Democrat, but the Alt-Right now houses some of them as well. Data suggest that the Democrats must face this diversity head on, but the stirrings of the nonreligious Alt-Right suggests that the GOP may face a reckoning between them and the still sizable white evangelical and conservative Catholic bloc. Further, the growth of the Nones suggests that the institutional influence of American Christianity is weakening. And, as always, while the major trends are significant in and of themselves, scholars would do well to investigate those groups in the (non)religious margins and their political priorities. Our biggest surprise in 2016 was the willingness of most religious Americans (even those in the most conservative camps of the GOP) to tolerate evident character flaws in a presidential nominee. This might be the bellwether indicator of increased privatization, individualization, and deinstitutionalization of religion in the public sphere. While religion in America continues to grow more diverse, its meaningfulness in decisions that affect the public good may grow less predictable and indirect, perhaps as a moderator of polarizing racialized interests.

\section{Matthew Avery Sutton}

I am not moving to New Zealand. I am not renouncing my citizenship. I am not even going on a spending spree at one of my neighborhood pot shops here in Washington State before Vice President Mike Pence shutters them. But I am rethinking some of what I do as a scholar and teacher. The victory of Donald J. Trump is an important moment in American history in many ways and for many reasons. Trump's success has particularly challenged and changed my thinking on the scholarship of American evangelicalism in two areas: the motivations behind evangelical political engagement; and the meaning and usefulness of the term "evangelicalism." 


\section{Evangelical Historiography and the Problem of Empathy}

The success of Donald J. Trump has forced me to question whether some of what I have written is wrong. And perhaps some of what friends and colleagues in the academy have written is wrong too. I came to this conclusion after seeing exit polls that indicated that Trump won 81 percent of the white evangelical vote.

As historians, our business is empathy. We immerse ourselves into the worlds and the worldviews of our subjects in order to make sense of them and to communicate why they did what they did. We don't have to like them, and we don't have to agree with their ideas or actions, but we need to understand them as they understood themselves. In the case of twentieth-century white evangelicals and their relationship to American politics, this means understanding why they voted the way they did, what motivated them to act, and how their beliefs intersected with their politics. In my research, most of what I have discovered, with only a handful of exceptions, were well-meaning people. Generally, I found my subjects to have others' interests at heart and what I interpreted as a sincere conviction that they should try to act with all the compassion, kindness, and concern for social justice that Jesus did. When they championed conservative political candidates, it was, I have argued, because they believed they were acting not out of narrow self-interest but in the best interests of the nation as a whole. They opposed the Social Security Act of 1935, for example, because they believed that the federal government could not help the poor or the aged as effectively as churches and local government. But they nevertheless passionately believed that something should be done to help the poor. When they defended tax cuts on the wealthy in the 1980s and again in the 2000s, which hurt entitlement programs, they acted because they truly expected that the savings to individuals and corporations that would result would create more, better jobs for more Americans. In other words, to be pro-tax cut on the wealthy was to be pro-poor, at least as they understood economic realities.

This was not to say that issues like race and racism did not play a role in their choices. Certainly in the pre-Civil Rights era, evangelicals, like most other white Americans, rarely thought of African Americans as their equals. And their own whiteness had a profound impact on how they saw their societies, how they read their Bibles, and how they understood the world. But was this at the heart of their opposition to New Deal liberalism? Were they afraid of an expanding state because they feared racial integration? I didn't think so. Furthermore, in recent decades, evangelicals have exhibited serious soul searching and seeming repentance over their 
racist past. But I am no longer so confident that evangelicals' antistatist politics can be separated from their fears of racial integration and equality.

We all know the many, many reasons that Trump represents what evangelicals have claimed to loathe, from divorce to gambling to foul language. The question I have to wrestle with is this: how should I understand Trump's success with evangelicals?

Perhaps the critics and skeptics of evangelicalism are right, and I was wrong. Perhaps evangelicals are and have always been nativists, afraid of anyone or anything that looks different. Perhaps racism and sexism and paranoia about gays and lesbians are driving their politics. Perhaps they never did care about their fellow Americans, about the greatest good for the greatest number, about embodying the virtues of Jesus, but instead have focused only on themselves and their white co-believers. Perhaps all of their theologizing was a facade. Perhaps their focus on racial reconciliation was not as important or as real as they claimed. Perhaps fear of those who are different is the primary emotion driving their reading of the Bible.

Or maybe evangelicals' politics are motivated by a simple, crass longing for power. For the last 150 years, evangelicals and their fundamentalist predecessors have believed that they had little real social and political power. Whether it was the FCC restricting their radio programs in the 1930s and 1940s, or the IRS going after Bob Jones University's racist policies in the 1970s, evangelicals have felt besieged. With the end of mandated school prayer and official school Bible reading in the early 1960s, the ubiquity of sex ed in schools, the normalization of same-sex relationships, pornography easier than ever to access, and marijuana legal in more and more states, evangelicals are feeling as lost as ever. Trump offered them not a partner to pray with, but a hitman whom they trust will root out and destroy much of what is threatening them. Pay-back is coming in the person of Trump to all the supposedly politically correct, godless liberals who have so angered evangelicals for the last few decades.

Or maybe evangelicals believe, as I have argued in American Apocalypse, that we really are nearing the end of time. Some of Trump's evangelical advisors on religious issues claimed exactly this during the campaign in justifying their support of the candidate. Many evangelicals believe that a secret, spiritual battle is under way of good against evil, light against darkness, Christ against Antichrist. The supposedly anti-evangelical and anti-God Obama presidency has threatened to bring the judgement of God down on the United States. Evangelicals may see Trump as the solution to this problem. They are ready for an unapologetic strongman to help them do end 
times battle. They believe that God will soon separate the "sheep from the goats," the righteous nations from the unrighteous. During the Final Judgment, God will decide which nations were faithful and which were not, and he will dole out punishments and rewards accordingly.

Trump's ideas meld perfectly with evangelical apocalyptic expectations as the battle of Armageddon seemingly nears. He promises to seize power and to use it for them. He claims he will restore religious liberty to evangelicals. He will prohibit Muslims from entering the country. He will defend Israel at all costs. He will fight abortion by adding conservative justices to the Supreme Court. He will rebuild the American military. He will destroy the nation's enemies. He will keep individual citizens well armed and prepared for battle. This is a man, in other words, who is not just able to beat Hillary Clinton but who is seeking to wage a real-world battle against evangelicals' enemies and a spiritual battle against the Antichrist. If Armageddon is coming, and many evangelicals believe it is, then there can be no one better to lead the United States than Trump.

There are many reasons that evangelicals may have voted for Trump. Maybe they are driven by xenophobia or are more covetous of power than I realized. Or maybe they are acting out their end times theology through their votes. But the one thing that few if any of them seemed to believe was that Trump represented the best "Christian" candidate or that he offered the most "Christian" policies. In fact, he represented just the opposite, which is why so many evangelical leaders and intellectuals, unlike their congregations, did not support Trump.

\section{Who Are the Evangelicals?}

The Trump campaign demands that we rethink the meaning and usefulness of the term "evangelical." "Evangelicalism" used to refer to a vibrant religious movement composed of men and women who claimed to have been born again, to have an ongoing personal relationship with Jesus, and usually to be part of a church community. Not anymore. Evangelicalism has become a shorthand way for Americans across the Protestant spectrum to identify as pro-God and pro-guns, and anti-immigrant, anti-gay rights, and anti-abortion. Evangelicalism now has little to do with Jesus and nothing to do with being part of a particular religious community.

If there is a remnant of evangelicals at all that has not been taken over by the Religious Right, it might be time for them to find a new identity. Since the time of Jesus, Christians have used many 
different terms to identify themselves and to distinguish their ideas and practices from other Christians as well as from other faiths. American evangelicalism emerged in the eighteenth century through a series of revivals led by Jonathan Edwards and George Whitefield. Its practitioners emphasized individual conversion, the authority of the Bible, Jesus' death and resurrection, and bringing others to the faith through missions. During the nineteenth century, American Protestants confronted various challenges. Higher critics attacked the historical accuracy of the Bible, and scientists promoted Darwinian theories of evolution as an alternative to traditional creation accounts. Some Christians moderated their faith and accommodated new intellectual trends. Others doubled down, clinging to what they believed was the old-time religion. Both groups, theological liberals and conservatives, claimed the name evangelical, which rendered it almost meaningless. As evangelical lost its descriptive power, it faded from use.

During the 1910s, some descendants of revival-oriented evangelicalism coined a new term. They began to call themselves "fundamentalists" to symbolize their return to the supposed "fundamentals" of the Christian faith. The term served them well until the infamous Scopes Monkey Trial of 1925. In Dayton, Tennessee, William Jennings Bryan prosecuted high school biology teacher John Scopes, who had taught evolution to his class in violation of a new anti-evolution state law. Bryan's powerful, media-savvy opponents, led by attorney Clarence Darrow and journalist H. L. Menken, seized on the term "fundamentalist" to ridicule Bryan and delegitimize his beliefs. Rather than use "fundamentalist" to describe the specific religious movement that had given birth to it, they transformed it into a wide-ranging slur. "Fundamentalist" quickly came to mean anti-intellectual, anti-modern, unenlightened, and often rural and southern.

For the next two decades, fundamentalists tried to salvage the term. But by the late 1940s, they had realized the cause was lost. A group of leading fundamentalists including Billy Graham recognized that they needed a new identity for their religious movement. They ditched fundamentalist and replaced it with the older, more historic term evangelical. This was a smart move that symbolized their rebranding in the wake of the Scopes trial and their claim to represent the true, historic Christian faith. But few people outside the fundamentalist-turned-evangelical movement noticed or cared.

Until 1976. In the midst of the Carter-Ford presidential campaign, journalists began to take note of the burgeoning religious movement that was coming to dominate the theologically conservative side of the American Protestant spectrum. Evangelical churches were thriving while historic, mainline churches were in decline. At 
the time the term had few political connotations. Evangelicals were culturally and politically engaged and had been for at least a century, but their views and voting habits were almost as broad and diverse as their numbers. Democrat Jimmy Carter claimed to be a born-again evangelical. So did Republican Gerald Ford. So did Jim Wallis, a politically liberal, social-justice oriented preacher living in the slums of Washington, D.C. And so did Pentecostal Pat Robertson, the head of a growing Christian media empire. Although most evangelicals were politically and socially conservative, to be an evangelical said little about one's party affiliation. Many northern and western evangelicals voted Republican while many southern evangelicals had long voted Democrat.

Then came the culture wars. Launched by savvy Republican operatives and a few evangelical preachers, over the course of the 1980s and 1990s, the culture wars transformed what it meant to be an evangelical. The Republican party claimed the mantle of God and family values while smearing the Democrats as the party of atheists and abortionists. During the Reagan presidency, the Religious Right aligned with the GOP and drew much of its strength from politically conservative, church-going evangelicals. In return, evangelicals gained access to the nation's Republican powerbrokers, which gave them a new respectability and substantially more cultural influence than they had had at any time since the Scopes trial. As the culture wars ratcheted up during the 1990s, evangelicals became even more closely identified with the Religious Right. Over time, the two movements became nearly indistinguishable. During the George W. Bush presidency, the culture wars so came to dominate American political life and partisan politics that to be an evangelical became almost synonymous with being a Republican. Evangelicalism had a new meaning.

The evolution of the term evangelical over the last thirty years has been far subtler than the transformation of the term fundamentalist in the 1920s. Few Americans-few evangelicals even-have noticed. But the recent presidential election suggests a very real split between church-going evangelicals, those who trace their heritage back to Jonathan Edwards and the Great Awakening, and culture war evangelicals, those who trace their heritage back to Jerry Falwell and the Moral Majority. Unlike in 1976, to identify as evangelical today is not to identify as church-going, born-again Christian. Rather it is to identify as a culture-war Republican who believes he has God's blessing on his political views. In other words, to be an evangelical is to be far more Mike Pence than Jimmy Carter. Evangelical has become the political identity of choice among white, socially conservative, 
generically Protestant Republicans regardless of their religious fervor or dedication to the evangelical religion.

Those evangelicals who still have a stake in defending a religion rather than a political platform might consider doing what their fundamentalist forebears did a couple of generations ago. They should let go of the term evangelical and find a new way to describe a faith that emphasizes the importance of having a personal relationship with Jesus and being part of a religious community. Some, like the leaders of Fuller Theological Seminary, want to hold onto the term-just like the fundamentalists of the 1930s-but they can't. The politics of the culture wars have killed American evangelicalism as any kind of a serious religious movement. Trump simply hammered the final nail into the coffin. For scholars, it is crucial that we understand that when Americans claim to be "evangelical," they no longer mean what Billy Graham and others meant in the 1960s.

In sum, the significance of the Trump election may not be clear for many years to come. But a few things are already evident. First, there is a stronger nativist strain in evangelicalism than many of us have realized, and as historians we should be less willing to take our subjects' words at face value; and second, the term "evangelical" is losing its descriptive value as a form of religious identity. What the future holds for the nation remains to be seen. Yet one thing is clear-with Donald Trump holding nuclear codes in one hand and a phone open to his Twitter app in the other, American evangelicals' anticipation of an imminent apocalypse may be closer to the mark now than ever.

\section{Grace Yukich}

Following Donald Trump's election to the U.S. presidency in November 2016, many political pundits highlighted the role played by dissatisfaction with the status quo among rural, white, working-class voters, whose economic woes were often attributed to immigration during Trump's campaign. But working-class voters were not the only reason for Trump's win, nor do anti-immigrant views fully explain his victory. Trump's election would not have been possible without the overwhelming support of white evangelical Christians, many of whom are not rural or working-class, and 81 percent of whom voted for Trump in the presidential election. Despite his vulgar behavior, multiple divorces and extramarital affairs, and lies during his campaign, a higher percentage of white evangelicals supported Trump than supported Romney in 2012, McCain in 2008, and even Bush in 
2004 (Pew Research Center, "How the Faithful Voted," 2016). White Catholics also showed strong support for Trump, more than for Republicans in recent presidential elections. In contrast, every religious group that is growing as a proportion of this country-Hispanic Catholics, "other faiths," and the religiously unaffiliated-voted overwhelmingly for Clinton.

The level of support for Trump among white Christians caused reactions of grave concern among people who support the rights of immigrants and Muslims, including some white evangelical leaders themselves. Still, despite the Trump campaign's central focus on restricting immigration and the rights of Muslims, as I will show, religious voters were not primarily divided by immigration. Large majorities of every religious group in the country, including white Christians of all stripes, agree that immigrants living in the United States illegally should have a path to legal status or even citizenship (Public Religion Research Institute [PRRI], "How Americans View Immigrants," 2016).

These trends reveal two important realities. First, in many ways, white Christians, especially white evangelicals, remain politically divided from other religious groups. However, this first reality obscures a second: that there may be more commonality on immigration across religious groups than it seems given strong white evangelical support for Trump and his anti-immigrant campaign. The primary difference may be not in values but in priorities, and priorities might change more easily. Is the formation of a broader religious coalition on immigrant rights possible, or is the religio-racial privilege that has differentiated white Christian priorities from those of other religious groups too difficult of a gap to bridge?

\section{White Christians and Immigration}

In The End of White Christian America, Robert P. Jones predicted that the dominance of white Christian America-which he defines primarily in terms of white Protestant Christianity, including evangelicalism, because of its historic cultural influence-is coming to an end. Demographically, he is right. Whereas almost seven out of ten Americans sixty-five and older are white Christians, only three out of ten Americans ages eighteen to twenty-nine identify in this way (PRRI, "American Values Atlas," 2014). This generational divide is primarily due to much larger numbers of younger Americans (1) coming from nonwhite Christian backgrounds or (2) identifying as religiously unaffiliated. Longitudinal data suggest these trends will hold up over time. In 1972, 74 percent of Americans identified as white Christians, but by 
2012, only 55 percent did (General Social Survey, 1972-2012). The days in which white Christians make up a majority of the nation do indeed seem to be coming to an end.

However, the 2016 election makes clear that white Christians, especially white evangelicals, are not yet ready to relinquish their religious dominance in American politics. Through most of American history, people elected to national leadership have been disproportionately Christian. (For instance, the $114^{\text {th }}$ Congress is 92 percent Christian, compared with 71 percent of the U.S. population, according to Pew.) Exit polls from the 2016 election show that both Protestants in general and white evangelicals specifically voted in disproportionately high numbers relative to their size. White Christians are declining as a proportion of the U.S. population, but as long as they continue voting in higher numbers than other religio-racial groups, their disproportionate religious influence on the country's politics will continue.

One could argue that white Christians supported Trump because they realize their decline is tied not just to the rise of the religiously unaffiliated, but also to changing racial and ethnic demographics in the United States, which are poised to make white Americans a racial minority in the coming years. The need to protect not just the dominance of Christian culture but of white Christian culture, embodied in opposition to the increase in immigration from nonwhite global regions since 1965, potentially shaped support for Trump. Indeed, while members of most religious groups are more likely to believe immigrants strengthen American society than to think they threaten traditional American customs and values, white Protestants (especially white evangelicals) are more likely to see immigrants as a threat than as a source of strength (PRRI, "How Americans View Immigrants," 2015).

But while white Christians are concerned about how immigration changes what they see as American customs and values, perhaps especially their own religio-racial traditions and privileges, it does not follow that they supported Trump because of his anti-immigrant views. Even among white evangelicals, the religious group with the most conservative views on immigration, only three out of ten support mass deportation of undocumented immigrants, a centerpiece of Trump's immigration policy platform during his campaign (PRRI, "How Americans View Immigrants," 2015). And exit polls showed that 34 percent of voters who support a pathway to legal status for undocumented immigrants voted for Trump, suggesting that a large minority of his supporters voted for him in spite of his immigration views, not because of them, many of whom may have been white Christians. 


\section{The Religio-Political Priorities of White Evangelicals}

If they disagree with Trump about immigration, a central part of his campaign, why did white evangelicals vote for Donald Trump in such high numbers? In a June 2016 poll conducted by Pew, 70 perecent of white evangelicals said the Supreme Court appointments were "very important" in deciding who to vote for in the presidential election. (Only 52 percent ranked abortion as "very important," suggesting that the Supreme Court appointments were about more than abortion for white evangelicals, a point to which I will return in a moment.) This played itself out in the election. According to exit polls, among voters who said Supreme Court appointments were "the most important factor" in their vote, 56 percent voted for Trump. A good proportion of white evangelicals likely did vote for Trump because of his promise to appoint anti-abortion justices, prioritizing that over issues like immigration reform.

To understand white evangelical concerns about the Supreme Court beyond abortion, one must turn to what was arguably the most controversial of Trump's policy positions: his views on targeting Muslims for religious discrimination. Though the majority of Americans oppose Trump's proposed ban on Muslim immigration, arguing that the Constitution's First Amendment prohibits showing preference for some religions over others, a majority of white Protestants, particularly white evangelicals, expressed support for the ban (PRRI, "American Values Survey," 2016). Ironically, white evangelical support of the discriminatory ban may have been due to concerns about their own religious liberties. In a recent Pew survey, 89 percent of white evangelicals said "terrorism" was a very important issue in the election, but evangelical fears of terrorism and support for bans on Muslims may in fact reflect deeper fears about Islam ("Evangelicals Rally to Trump," 2016). Because some, though not most, Muslim-majority nations restrict the religious freedoms of Christians in favor of Muslim rights (see Brian Grim and Roger Finke, The Price of Religious Freedom Denied, 2010), some evangelicals worry that growth in the U.S. Muslim population might lead to oppression of Christians.

While it is hard to understand this concern when 71 percent of the U.S. population is Christian and only 1 percent is Muslim, these fears of religious oppression must be understood as historically and theologically rooted in (1) long-term antipathy, distrust, and competition between Christians and Muslims reaching back at least to the Crusades, (2) growth in evangelicals' fears of religious persecution by communists during the Cold War era, and (3) a religious identity 
based in countercultural embattlement that is central to evangelical Christian theology and identity. The first two of these are well known, but the third is less often recognized. On this, sociologist Christian Smith's book American Evangelicalism: Embattled and Thriving (1998) remains essential for understanding the "culture wars" and evangelicals" role in them. The book's extensive interviews and surveys with selfidentified evangelical Christians show that American evangelicals have traditionally maintained strength by drawing strong boundaries with the culture around them, regardless of what that culture has looked like, creating in-group solidarity and commitment in the process. Because evangelical Christians believe they must be "in the world but not of the world," similarities to nonevangelicals are seen as negatives rather than positives, and persecution by the wider culture is considered evidence of being a true Christian. In other words, "embattlement" is a core part of evangelical theology and identity.

Now that evangelical Christianity is no longer thriving to the extent it was when Smith's book was published almost two decades ago, it is likely that evangelical Christians feel even more embattled. Indeed, recent survey research suggests this to be the case. An increasing number-almost half-of white evangelicals feel it has become more difficult to be an evangelical Christian in the United States in recent years (Pew, 2016). It probably has become more difficult in some ways: for example, the conservative views many evangelicals hold about same-sex relationships are no longer the norm, legally or culturally, in the United States. Perhaps for this reason, though Christians make up an overwhelming majority of the U.S. population and hold disproportionate power in politics, a significant portion of evangelical Christians (27 percent) think of themselves as a member of a minority because of their religious beliefs (Pew, 2016).

Instead, current research suggests that evangelical Christians, Catholics, and Jews are all viewed about equally as positively by Americans, and much more positively than any other religious groups (including the religiously unaffiliated), so it is difficult to conceive of evangelicals as an oppressed minority group (Pew, "How Americans Feel about Religious Groups," 2014). However, public discourse during the Obama era suggests that evangelicals have experienced embattlement along two main lines: (1) the legalization of same-sex marriage and (2) the provision of the Affordable Care Act that requires some religious employers to provide health insurance for employees that includes birth control coverage, even if the employers oppose the use of birth control for religious reasons. In both cases, evangelicals are losing something, but most of what they are losing is not their own religious freedoms but the legal privilege to dictate that nonevangelicals 
follow evangelical norms and values that they do not share. Loss of privilege sometimes feels like oppression to people who are accustomed to holding positions of power over others.

To summarize, the high percentage of white evangelicals who voted for Trump should be understood not necessarily as an endorsement of his anti-immigrant, racist, and xenophobic remarks but rather as a continuation of the culture wars, which many scholars and commentators thought had largely ended. White evangelicals voted for Trump because they are concerned about abortion and because they are worried about their own standing in American society, as they perceive themselves to be a religious minority being threatened by Muslim immigration, cultural and legal shifts such as acceptance of same-sex marriage, and their own stagnation and even decline as a percentage of the total U.S. population.

\section{Is Religious Common Ground on Immigration Possible?}

Though white evangelicals may not change their beliefs about the morality of "culture war" issues like abortion and same-sex marriage in the near future, it is possible that they might start to see these issues as less central to their religious identities than they have in the past. Younger evangelicals are less concerned about same-sex relationships, less likely to identify as conservative, and more likely to be concerned about the environment and poverty compared with older evangelicals (Pelz and Smidt, 2015). Also, as demographic shifts occur within U.S. evangelicalism, which is becoming more racially and ethnically diverse (Pew, "Religious Landscape Study," 2015), issues of race and immigration may garner an increased focus: congregations with more immigrants are more likely to view immigrants in a positive light (Pew, "Few Say Religion Shapes Immigration, Environment Views," 2010).

As for the other reason white evangelicals likely supported Trump—issues of religious liberty_if evangelicals are able to bridge long-standing racial divisions to form a broader evangelical identity that includes white, black, and Hispanic evangelicals, then perhaps white evangelicals will not feel the need to protect their religious freedom to the extent that they currently do. Evangelicals on the whole are not declining as a percentage of the U.S. population the way that white evangelicals are. However, the central theological issue remains: that the need to maintain distinction from and embattlement against supposedly hostile outsiders remains a central part of American evangelical identity, which means that evangelicals may always find it difficult to see themselves as part of the country's powerful majority (i.e., Christians) 
rather than as an oppressed minority that needs to protect its own interests.

In addition to these demographic transformations that may shift the priorities of white evangelicals, intentional battles for the power to define what it means to be religious-both within evangelicalism and within Christianity and other communities of faith more broadly-may change the political priorities of all people of faith from a focus on personal morality to an emphasis on structural issues like entrenched poverty, immigration, and climate change. These intrareligious fights deserve increased attention from scholars of religion and politics in the coming years. My book One Family under God: Immigration Politics and Progressive Religion in America (2013) chronicles one such battle, the New Sanctuary Movement.

The New Sanctuary Movement emerged in 2007 as a national network of local faith-based coalitions responding to a legislative and cultural environment they perceived as increasingly hostile to immigrants. The religious activists in the movement-mostly Christians, though there was also Jewish and Muslim involvement—-sought to humanize undocumented immigrants by highlighting their status as members of families: of human families, of the human family, and of the family of God. Religious communities partnered with mixed-status immigrant families, where typically a parent is undocumented and children are U.S. citizens, and called on fellow members of their religious traditions to recognize how a focus on "family values" necessitates a focus on keeping these families together by reforming the immigration system.

In doing so, New Sanctuary activists sought both political change (e.g., an end to deportation, comprehensive immigration reform) and religious change- they worked to help more religious people to see immigration as a religious issue. They were confident that, if more religious Americans relied on their religion's teachings to determine their positions on immigration rather than basing their views on their own perceived economic self-interest, their views on immigration would change and more religious people would see immigration reform as a priority. As of 2010, only 12 percent of white evangelicals said religion was the biggest influence on their immigration views, compared with same-sex marriage (62 percent) and abortion (53 percent) (Pew, "Few Say Religion Shapes Immigration, Environment Views"). However, as many others have argued, white evangelicals' focus on these issues is historically constituted, not theologically essential (see Brian Steensland and Philip Goff, eds, 2013). As a group placing special emphasis on scripture, far fewer biblical verses are connected to issues of abortion and same-sex relationships compared with 
verses dealing with hospitality to strangers-including the parable of the Good Samaritan, one of Christian scripture's most enduring stories-suggesting that white evangelicals could become open to prioritizing immigration.

However, leaders of white evangelical congregations would have to play an active part in these changes, as they play an important role in creating focus on the issues white evangelicals currently prioritize. According to the same 2010 Pew poll mentioned above, only 16 percent of white evangelicals had heard their pastors speak about immigration in church, compared with 52 percent whose pastors had spoken about laws regarding homosexuality and 65 percent whose pastors had spoken on the issue of abortion. There are important signs that at least some white evangelical leaders are attempting to place greater emphasis on immigration. At its 2016 annual meeting, the Southern Baptist Convention (the largest Protestant denomination in the United States, the vast majority of whom are white evangelicals) passed a resolution calling for Southern Baptist churches and families to welcome refugees into their congregations and homes, placing them in stark contrast with both then-candidate Trump and many state governors who had rejected Syrian refugees from resettlement in their states.

Many white evangelicals who voted for Trump may be experiencing moral conflict about how their votes affirmed his often inaccurate and xenophobic statements about immigrants and Muslims, fanning the flames of hatred against some of the nation's most vulnerable residents. Most white evangelicals support a path to citizenship, so some may be looking for a way to show that they do, in fact, welcome immigrants. In this way, Trump's election may have created an unexpected opportunity for the formation of broader religious partnerships on immigrant rights. Putting aside long-standing divisions between groups accustomed to working on different sides of the political aisle is difficult. But under the circumstances, perhaps an increased number of white evangelicals will join with black, Hispanic, and Asian Christians, Muslims, and others in showing compassion toward immigrants and their families as religious and political priorities. 